CHAPTER TWO

\title{
THE ISRAELI INCORPORATION REGIME
}

\section{Colonizing THE LAND OF MiLK AND Honey}

The four great powers are committed to Zionism. And Zionism, be it right or wrong, good or bad, is rooted in age-long traditions, in present needs, in future hopes, of far profounder import than the desires and prejudices of the 700,000 Arabs who now inhabit that ancient land ....

Memorandum by Mr. Arthur J. Balfour, August 11, 1919 (Woodward and Butler 2005a, 208).

Modern political Zionism is, in both thought and practice, a product of a colonial world order. The depiction of the Zionist movement as a settler colonial project is neither new, nor was it a characterization that Zionist ideologues shied away from. ${ }^{1}$ Even Altneuland ("Old-New Land"), a novel written by the father of political Zionism, Theodor Herzl, which aimed at propagating his utopian vision of a Jewish Palestine, openly adopts the language and logic of colonialism. While not a direct blueprint for Herzl's Jewish state, nor a manuscript that can be brought to the level of reality, Altneuland is one of the first and most comprehensive literary accounts of a Jewish society in Palestine. Unlike Herzl's more famous publication, Der Judenstaat ("The State of the Jews"), which served as the ideological bedrock and outlined the organizational structure of Zionism, Altneuland does depict an existing Arab population in Palestine. However, in its representation of Arabs in Palestine, it too places them within a hegemonic colonial order. Indeed, there is a connection between the bedrock of modern Zionism (including its liberal-Zionist variant) and that of the colonial

\footnotetext{
${ }^{1}$ One of the most lucid and thorough readings of the Zionist movement as a colonial project was written by Maxime Rodinson. Arguing that the Zionist movement to create the State of Israel effectively corresponds into the European-American project of colonialism, Rodinson concludes: "Wanting to create a purely Jewish, or predominantly Jewish, state in an Arab Palestine in the twentieth century could not help but lead to a colonial-type situation and to the development (completely normal, sociologically speaking) of a racist state of mind, and in the final analysis to a military confrontation between the two ethnic groups" $(2004,74)$. Important insights into studies of the Zionist colonization of Palestine can also be found in Piterberg (2008).
} 
logic of the fictional text. Not only do they share Herzlian thought as a central tenet in their formation and development but also, more importantly, they both conjure the dream of integration, emancipation and coexistence.

Intended for a non-Zionist audience and aimed at securing non-Jewish support for the Zionist movement, Herzl uses the fictional structure of Altneuland to express "his own visions of Zionism in its purest, most uncompromising form" (Herzl 1987, vi). Beginning in 1902, the novel follows the main character, Friedrich Löwenberg, a twenty-three year old Jewish Viennese lawyer, who, alienated by the decadence of JewishEuropean bourgeoisie, decides to join an Americanized Prussian philanthropist named Kingscourt with a distaste for humankind to withdraw to a remote island. "Disgusted with life," Löwenberg agrees to a "life-long obligation" to Kingscourt, and decides to dissolve all of his existing social, cultural and financial ties to the Jewish bourgeois circles in which he had long sought inclusion (Herzl 1987, 32). The novel details their brief visit to Palestine during their journey to the island in 1902 and their observations of the land two decades later during what they had anticipated would be a brief return to civilization. Their second visit to the land reveals that during their twenty year absence: the "empty and deserted" town of Acre had undergone a "miracle;" Haifa had become a "magnificent city" with "cosmopolitan traffic in the streets" that "seemed thoroughly European;" Tiberias had become the "Garden of Eden ... a new gem ... [with] verdure and bloom everywhere;" Mount Hermon overlooked "the smaller ranges and the rejuvenated land;" Jericho and the Jordan Valley worked with "the newest and best agricultural machinery available" and produced "abundant crops ... which brought rich profits;" the Dead Sea had been stirred to life; and Jerusalem, once a "picture of desolation" now had its sacred hills endowed with "new, vigorous, joyous life [and] many splendid new structures," which transformed the ancient city into a "twentieth century metropolis" (Herzl 1987, 58-59, 61, 161, 241, 247). All in all, Palestine had ascended from a "forsaken" land, "a state of extreme decay [with] poor Turks, dirty Arabs, [and] timid Jews ... indolent, beggarly and hopeless," into a technologically advanced, agriculturally cultivated, intellectually progressive, economically prosperous "Promised Land" (Herzl 1987, 42). A "truly modern commonwealth," the Palestine built by the Zionist colonialists had been "fructified into a garden and a home for people who had once been poor, weak, hopeless and homeless" (Herzl 1987, 223, 244).

The utopian vision of a Jewish commonwealth depicted in Altneuland develops according to a clear colonial logic: through the immigration of a 
population of superior human intellect and capacity, a settler-colonial state is established according to rational plans that effectively exclude a wretched and underdeveloped indigenous population from the discourse of historical, cultural, political and legal rights. A hegemonic strategy is thereby played out so as to detach the native population from the historical record of the space, while simultaneously entrenching the identity and legitimate claim of the settler population over the colonized land. As outlined in Altneuland, immigrating "in the full light of day," the "Jewish settlers who streamed into the country had brought with them the experience of the whole civilized world" (Herzl 1987, 100, 127). Here surfaces one of the defining characteristics of the Zionist brand of colonialism: instead of claiming to apply full or partial control over the territory of another population, settlement of the land is presented as a process of reclamation by, or return to, its rightful custodians. The settlers are posited as indigenous to the land. "We led our people back to the beloved soil of Palestine," says David Littwak, Löwenberg's travel guide, "[and] milk and honey once more flowed in the ancient home of the Jews" (Herzl 1987, 151, 241).

Using the language of colonialism, Altneuland also expands on a familiar universal humanitarian argument posited by the European colonialists of the time: settling the land will result in the progress of humankind as a whole. Throughout the text, the founders of the Old-New-Land remark that its foundations were laid in Europe. Littwak notes, colonized Palestine "punish[es] only those crimes and misdemeanours which were penalized in enlightened European states" (Herzl 1987, 98). Created in the image of Europe, the value of the achievements of the Jewish commonwealth in the areas of "education ... land reform, charity organization, social welfare ... the role of women ... the progress of applied science," literature, and technology are strictly measured in comparison (Herzl 1987, 223). That the "Jewish peddler ... [can carry] herself so modestly and yet with such dignity beside the great English lady" is proof that "Jews have risen to their 'proper place' among the 'great nations' and 'noble races'."' In Herzl's novel, and within the Zionist framework, the logic of colonialism propagates the Jew as a liberal cosmopolitan "colonizer for progress" and Palestine is reduced to an "experimental land for humanity." 3 Overall, what is revealed in the fictional structure of Altneuland is the extent to which the Jewish national movement and its pundits employed the

\footnotetext{
2 See Herzl 1987, 258; Stolow 1997, 60.

3 See Stolow 1997, 6o-61; Herzl 1987, 5 o.
} 
ideological and conceptual model of colonialism, and cooperated with the forces of European imperialism, in their justification of Jewish statehood.

Israeli sociologist Baruch Kimmerling points out that, since its inception, Zionism was adept at distancing itself from the colonial milieu within which it developed:

Zionism emphasized the uniqueness of the 'Jewish problem': anti-Semitism, persecution, and, later, the Holocaust. It presented itself as the sole realistic and moral solution. Thus, the Jewish immigration movement was able to successfully present itself as a 'return to Zion', the correction of a cosmic injustice that had gone on for thousands of years, and as totally disconnected from other European immigration movements to other continents (Kimmerling 2002a, 1122).

Granted, the historical record shows that prior to the advent of Zionism as a national movement, Jewish migration to Palestine spanned a number of centuries and was mainly driven either by religious motivations, or as a result of the socio-political circumstances for Jews becoming unbearable in other places (Van Der Hoeven Leonhard 2005a, 115-116). During these periods, however, and for almost thirteen centuries, the mainly peasant indigenous Arab population had remained on their native soil, and managed to survive the range of "natural catastrophes, epidemics, famines, devastating armies, foreign occupiers and tax collectors" that befell the land. The discourse of Jewish immigration to Palestine radically transformed after World War I, whereby Zionism became intensively reformulated around European notions of statehood, colonialism and imperialism. ${ }^{4}$ Spearheading the political Zionist discourse, Herzl sought both Jewish and European support for his national project through "extortion, and stimulation of anti-Semitism" (Van Der Hoeven Leonhard 2005a, 118). As outlined by Walid Khalidi, Herzl's framework of analysis can be summarized as follows:

4 Maxime Rodinson outlines the ideological and conceptual influences and parameters of Zionism, analyzing it in terms of its colonial character. In this text he explains that "the dominant outlook of European chauvinism" along with the "ethnocentric and racially exclusive ideology ... [of ] European bourgeois nationalist doctrines" were the main sources of influence and main spaces of organizing and support the Zionist colonists in Palestine. Rodinson writes, "Although very few Zionists had come from Great Britain, this country, in regard to Palestine, played the role of mother country for a colony that was being settled" (2004, 10, 11, 62-71). As such, what is called the Zionist 'rebellion' or 'insurgency' against British rule in Palestine during the 1940 s was essentially a dispute between the colonizers and the colonial centre fuelled by their political and material interests. 
[A]nti-Semitism, which was the root of the Jewish problem, was ineradicable, the Jews constituted a people in the sense of a nation, and the Jewish problem was consequently a national problem which could only be solved by the gathering into one state of all Jews who wished to retain their Jewish identity, and by the complete assimilation and effacement as Jews of the remnant still scattered among the nations (Van Der Hoeven Leonhard 2005a, 118).

In other words, Herzl's arguments go as follows: the Jewish problem exists because anti-Semitism is both real and ingrained in Christian Europe, and because the Jews constitute a nation, the Jewish problem is therefore a national problem. Through the effective merging of Jewish identity with Zionist identity, not just as collectivities but also as a general mechanism of incorporation, Zionism has provided Israel's settler-colonial framework with a certain social and historical validity. As alluded to in Chapter Four, this is also the case for various Western liberal-democratic academic circles. Despite this, the current scholarship from critical Arab and Jewish historians, social scientists and political scientists - particularly those in Israel - indicates that at a socio-political and ideological level the Zionist project has had to constantly defend the legitimate existence of Israel as a Jewish state. At the same time, at a legal-juridical level, the Zionist movement has also repeatedly had to explain its choice of Palestine as its territory for settlement to the international community. ${ }^{5}$

On this, the theoretical framework of analysis adopted by Israeli sociologist Gershon Shafir in his account of Israeli colonialism is particularly radical, and crucial. ${ }^{6}$ Shafir draws direct conceptual and historical links between post-1967 Israeli colonization in the West Bank and Gaza and pre-1948 Zionism. ${ }^{7}$ While acknowledging that the mode of Jewish colonization and settlement in Mandate Palestine differed and tailored itself according to the political, legal and economic realities of its time, he contends that the essence and nature of the Zionist project stayed colonialist. Shafir writes:

5 Kimmerling 2008, 182. Zionist arguments justifying Mandate Palestine as its target territory for settlement are also explained in Morris (1995).

6 American-Israeli historian Gabriel Piterberg writes that "Shafir's work on the initial stage of Zionist colonization is one of the most fundamentally radical critiques of Zionism I am aware of, a fact masked by the work's arid register. .... It is also the most self-conscious attempt to reinterpret Israeli history within the framework of the comparative study of settler societies .... Shafir regards colonization not as a fleeting moment of formation but as a continually present and underlying structure" $(2008,62-63)$.

7 See Shafir (1996) and (1999). The latter text is a synopsis of the major contentions of the former text, with additional insights included by the author. 
Where others see historical bastards, I find a streak of historical ancestry. I offer, therefore, a theoretical and conceptual perspective that highlights the continuous centrality of colonization in Zionism and at the same time gives appropriate weight to the changes that have taken place, under new circumstances, within the framework of settlement. European colonialism, after all, did not create just one model of overseas society, and it seems to me that we can understand the transformation of Israeli society since 1967 most fruitfully as a transition from one method of European colonization to another one (Shafir 1999, 83).

Shafir begins his comparative analysis by outlining the specific attributes of the Zionist means of colonization: unlike European hegemonic powers, the Jews had no organized polity until the beginning of the British Mandate; areas earmarked for settlement were selected ideologically by Zionists and not based on their economic potential; only a minor segment of the indigenous Palestinian population were nomadic when Zionist settlement was underway and most were in the process of expanding their areas of residence to coastal and inland areas; purchase was considered a means of territorial accumulation by Zionist settlers unlike their European counterparts who considered colonized land as free; Jewish farmers employed seasonal unskilled wage labour unlike the contract-based or slave workers in European colonies; and many of the Jewish colonizers were refugees and lacked independent resources (Shafir 1999, 84-85). These differences between the Zionist 'pure settlement' project and other frontiers of settlement do not indicate a non-colonial character of the Jewish national movement, explains Shafir. Instead, these differences existed to ensure the smooth colonization of Palestine given the particularly difficult state of the land and circumstances of the incoming settlers. To Shafir, colonialism is not a cursory or transient effect of Zionism, but instead serves as its congenital backbone. ${ }^{8}$

Shafir distinguishes between two phases of Zionist settlement in Palestine, what is called the First Aliyah from 1882-1903 with about 20,00030,000 Jewish immigrants and the Second Aliyah from 1904-1914 with about 35,000-40,000 Jewish immigrants, the latter during a time where approximately 425,000 Palestinian-Arabs lived in Palestine (Shafir 1999, 86-88). The former period developed into what he calls an 'ethnic

8 This point is deepened and expanded upon in the recent work of Gabriel Piterberg whose intricate and insightful account of the Zionist ideology and ethic explains how the Zionist movement was an unexceptional colonial project compared to those initiated by European hegemonic powers (see Piterberg 2008). 
plantation colony' fuelled mainly by a large low-paid and seasonal Arab labour force and a smaller better-paid Jewish labour force. The contradiction between market-based colonialism and Jewish national aims resulting from the considerable use of Arab labour stimulated a change in the colonial direction during the second major phase of immigration. The arrival of Jewish immigrants during the Second Aliyah whose organized workers formed the ranks of the Labour Movement generated a change in the colonial struggle from the 'conquest of land' to the 'conquest of labour' as a central concern. However, despite this shift, Shafir contends that the ultimate aim of furthering Jewish colonialism and establishing a pure settlement colony has remained unchanged.

This analysis is significant given the ripples it creates within some of the most critical Israeli political circles. Any depiction of Zionism as a colonial project is considered a provocation by the vast majority of Israeli society, and translated to self-hatred and disloyalty to the state. That said, as Israeli historian Ilan Pappé notes, the comparative colonial discourse does appear among a few critical Israeli scholars who tend to self-identify as the Zionist Left. But this too is a limited analysis. Pappé explains:

Critical Israeli academicians ... tend to see the year 1967 as a watershed between a pre-1967 moral, contained and basically united Israel and a post-1967 occupying, expansionist and divided Jewish state. Hence, they are willing to point to colonialist features in the Israeli conduct in the occupied territories and trace all the present social and political predicaments to the making of Greater Israel in 1967 (Pappé's commentary in Shafir 1999, 81).

Shafir's reformulation of Israeli history within the parameters of a colonial-settler scheme, and one that simultaneously acknowledges the "particular cast" of Zionist colonialism along with its "fundamental similarity with other pure settlement colonies," refuses the above demarcation. The colonial logic of pre-1948 Zionism was amended in its post-1967 realization, yet remained central to the Zionist project of nation-building. It is upon this understanding that this book seeks to examine the inclusive and exclusive dynamics faced by Palestinian-Arab citizens in contemporary Israel. The colonial logic of pre-1948 Zionism will be shown to resurface in contemporary Israeli democracy, at the legislative, declarative, structural, and operational levels. In other words, the historical matrix of colonialism within which the Jewish national movement burgeoned is the main source of the multifaceted racial discrimination faced by PalestinianArab citizens today. 


\section{A Multifaceted Discrimination}

Discrimination against non-Jewish citizens penetrates to every corner of Israeli society, from the private to the public sphere, and at social, civil, legal and political levels. According to Arab political scientist As'ad Ghanem, the channelling of rights through Israel's policy of Jewish dominance can be analyzed at three different levels: the declarative level, the structural level, and the operational level (Ghanem 1998). What becomes evident in the proceeding analysis is that while legal and operational policies do exist in Israel that aim at alleviating the depraved circumstances of marginalized groups and collectives within its society, these measures have largely been fruitless. At best, policies aimed at reducing marginalization are both insufficient and ineffective and, at worst, they are rendered inapplicable to the case of Palestinian-Arab citizens. Instead, such measures are often employed by their liberal-Zionist adherents as a distraction from any genuine conversation about the ensconced inequality of Israel's Arab citizenry.

Before I begin to outline the extent of the entrenched discrimination against Arab citizens at the declarative level, the structural level, and the operational level, I would like to examine recent devastating developments taking place in Israel at the legislative level. Here, the legislative level is treated as a distinct area of analysis because of its particular function in the reproduction of the Jewish nation-state.

\section{Legislative Level}

Questions of representation and democracy are not new to the Arab population in Israel. They emerged with the establishment of the Jewish state and have grown increasingly acute since the Al-Aqsa Intifada. This period of Arab existence in Israel witnessed the development of an additional mechanism of disenfranchisement to the existing inferior political, social, and legal status of Arabs in Israel, and came in the form of a strong attack on Arab citizenship rights and status. Following the outbreak of the second Intifada, the state began to propose legislation aimed at diluting, both formally and informally, the civil status of Palestinian citizens and further impeding their existing limited sphere of political action. Through legislative and constitutional amendments, governmental policies, and the radicalization of the public discourse on Arabs in Israel, previously dormant political beliefs and biases were enabled, thereby generating new forms of discrimination. Having identified more than thirty key laws 
that directly discriminate against Palestinian citizens of Israel, Adalah: The Legal Center for Arab Minority Rights in Israel (hereafter 'Adalah') writes:

The current constitutional situation has allowed the State of Israel to enact laws that are either discriminatory on their face, in that they relate only to the rights of Jews in Israel or abridge the rights of Arab citizens of the state, or use neutral language and general terminology but have a discriminatory effect on Arab citizens. ${ }^{9}$

Indeed, Arab citizens of Israel were a major topic in the 2009 election campaigns that brought in the previous eighteenth Knesset and saw one of the most right-wing government coalitions in the history of Israel come to power. That administration has since been topped by the recently elected nineteenth Knesset featuring an even more right-wing government coalition that includes religious and ultra-orthodox Jews, along with a disproportionately high representation of Jewish settlers of the West Bank in the parliament. ${ }^{10}$ The rise of right-wing representation in the Knesset has, since 2009, introduced numerous discriminatory laws that target Palestinian-Arab citizens of Israel, along with Palestinians in Jerusalem, the West Bank and the Gaza Strip, and the Palestinian refugee population. These new refugee land laws and bills - which continue to surface on a regular basis ${ }^{11}$ - are too many to mention here, but there are a few that deserve special attention:

9 Adalah: The Legal Center for Arab Minority Rights in Israel, The Inequality Report: The Palestinian-Arab Minority in Israel, March 2011: 14, http://www.adalah.org/upfiles/2011/ Adalah_The_Inequality_Report_March_2011.pdf.

10 Though beyond the scope of this book, it is worthwhile to mention that racist policies targeting the Palestinian citizenry are not only limited to Israeli right-wing, ultra-nationalist or orthodox political parties. For instance, widely conceived as a centrist political party, Yesh Atid (The Future Party) is nevertheless in agreement with the parties on the extreme right on most of the major political and social issues in the country. This includes, among others, support for demographic engineering to maintain a Jewish majority, legally sanctioned Jewish domination in all spheres of society, vehement opposition to the proposed paradigm of Israel as a 'state for all its people', as well as support for illegal Jewish settlements in the West Bank. In fact, during the 2013 Knesset elections, Yesh Atid even launched its election campaign in the illegal Ariel settlement, the fourth largest of its kind in the West Bank. For more, see Neve Gordon, "Yair Lapid: The southern man and his cosmopolitan ghetto," Al Jazeera English, February 12, 2013, http://www.aljazeera.com/indepth/ opinion/2013/02/2013211112856254494.html.

11 An updated list of the existing legislation which specifically targets Palestinian citizens and affects the community disproportionately is provided by Adalah: The Legal Center for Arab Minority Rights in Israel, New Discriminatory Laws and Bills in Israel, June 2012 (the source of much of what follows), http://www.adalah.org/Public/files/English/ International_Advocacy/New_Discriminatory_Laws_June_2012_Update.pdf. 


\section{i. Amendment to The Israel Lands Administration Law (1960)}

Approved by the Knesset on August 3, 2009, this law implements broadbased land privatization measures. It stipulates that most of the land currently classified by the state as "absentees property" and owned by the Palestinian refugees and internally displaced persons, along with some of the lands of demolished and evacuated Arab villages, and land otherwise seized from Palestinian citizens, can be sold to private investors and is rendered inapplicable to any future restitution claims. Further, this law bestows upon representatives of the Jewish National Fund (Keren Kayemeth Le-Israel, hereafter 'JNF') the decisive authority over the land in a new Land Authority Council, set to replace the Israel Lands Administration (hereafter 'ILA') which currently oversees the use of 93 percent of the total land in Israel. Totalling about 800,000 dunums, these areas include the property of refugees currently located in mixed Arab-Jewish cities, along with land that has been zoned or planned for development.

\section{ii. Amendment to The Land (Acquisition for Public Purposes) Ordinance Law (1943)}

Approved on February 10, 2010, this new amendment, asserts state ownership of land confiscated under this law even including cases where the land has not been used for its original confiscation purpose. In other words, this law enables the state to put off using the confiscated land for its original confiscation purpose for seventeen years, and prohibits landowners from demanding the return of the land that is not used for the original confiscation purpose if it has been turned over to a third party, or if more than twenty-five years have passed since the confiscation. Originally a British Mandate-era law, this legislation has, since its inception, continuously been used by the state to enable the Minster of Finance to confiscate land for public purposes. Applied in conjunction with other laws such as The Land Acquisition Law (1953) and The Absentees' Property Law (1950), this law serves as the fuel that drives state-led initiatives to confiscate Palestinian-owned land in Israel. It broadens the decisive powers of the Finance Minister to seize land, even permitting the Minister to announce new purposes. Evidently, this new amendment aims to preempt future potential lawsuits initiated by Palestinians to reclaim confiscated land. Not only has there been more than 25 years since the majority of Palestinian land was seized, but large sections of this land has been transferred to third party Zionist organizations, such as the JNF. 


\section{iii. The Admissions Committees Law}

Passed on March 24, 2011, this law calls for "admission committees" to operate in almost 700 agricultural and community townships, accounting for 68.5 percent of all towns in Israel and around 85 percent of all villages built on state land in all of the Naqab and Galilee. Serving as decisive bodies that select applicants for housing units and plots of land, these committees are given full discretion to approve or deny individuals the right to live in these towns. Composed of "a representative from the Jewish Agency or the World Zionist Organization," the ambiguous and subjective criterion of "social suitability" adopted by these communities stands to reproduce and entrench racially segregated towns, communities and villages throughout Israel. Though legal provisions for adhering to the right to equality and preventing discrimination are included in this law, it nevertheless allows these committees to refuse applicants considered "unsuitable to the social life of the community... or the social and cultural fabric of the town." As a result, entire ethnic communities are filtered out as applicants. In fact, this law also allows admissions committees to include criteria selected by the individual communities themselves according to their particular characteristics, and encompass even those townships that are self-defined as maintaining a "Zionist vision."

\section{iv. The 'Nakba Law'}

Passed on March 22, 2011, the amendment to The Budget Foundations Law (1985) is popularly called the 'Nakba Law'. This law enables the Minister of Finance to reduce or remove state-funding to an organization or institution if it sponsors or advocates an initiative that challenges the existence of Israel as a "Jewish and democratic state," or if it recognizes "Israel's Independence Day or the day on which the state was established as a day of mourning." ${ }^{2}$ Outlawing the traditional marking of Israel's official Independence Day, May 14, 1948, as a national day of mourning for the loss of their homeland and the displacement of their people, this law specifically targets the right of the Palestinian citizens of Israel. Although its original draft prohibited any and all commemoration of the Nakba, the approved draft of the 'Nakba Law' targets state-funded institutions, including schools, research centres, civil society organizations and political groups with the threat of a fine of up to ten times the funds used for the commemoration.

12 Adalah: The Legal Center for Arab Minority Rights in Israel, The Inequality Report, 40. 
An integral part of the Palestinian narrative, not to mention a documented historical fact, memorialization of the experience of the Nakba is vital for the preservation of their cultural and national ties. This law infringes on the rights and freedom of opinion and expression of Palestinian citizens, causing immense damage to any communal, cultural, educational and political initiatives aimed at mutual understanding. Interestingly, in commenting on this law, former Foreign Minister Avigdor Lieberman, a member of the right wing Yisrael Beiteinu party that sponsored the bill, said "there is no other normal country that funds events comparing its establishment to a catastrophe." 13 What surfaces here is that, for Lieberman, the Nakba is merely being compared to Israel's Independence Day, and is not understood as a direct and simultaneous effect of the establishment of the state.

\section{v. The NGO Foreign Government Funding Law}

Passed in February 2011, The Duty of Disclosure for Recipients of Support from a Foreign Political Entity Law (2011) inflicts extensive reporting stipulations on NGOs. It compels them to submit and publish quarterly reports on all financial support obtained from "foreign governments or foreign publicly-funded donors, including detailed information on any oral or written undertakings made to the funders" - all of which ought also to be publicized on the websites of that NGO, the Ministry of Justice and Registry of Associations. These reports must include details of the amount and purpose of the funds, the identity of the donor organization, and details of all correspondence between the donor and NGO. The drafters of this law claim that it aims to achieve increased transparency among NGOs, but as stated by Adalah, "these provisions are superfluous since every nonprofit organization in Israel is already required under Israeli law to list its donors and other financial information on its website and to report annually to the government, specifying whether foreign governments have donated money." ${ }^{14}$ Nevertheless, this law impedes the ability of NGOs to

13 Jonathan Lis, "Human rights groups petition High Court to overthrow 'Nakba Law,," Haaretz, May 4, 2011, http://www.haaretz.com/news/national/human-rights-groups -petition-high-court-to-overthrow-nakba-law-1.359802. In a comment on this law, Arab MK Haneen Zoabi said: "This is a kind of law to control our memory, to control our collective memory. It's a very stupid law which punishes our feelings. It seems that the history of the victim is threatening the Zionist state." See Jillian Kestler-D'Amours, "Israel criminalizes commemoration of the Nakba," The Electronic Intifada, March 29, 2011, http:// electronicintifada.net/content/israel-criminalizes-commemoration-nakba/9289.

14 In an article in Haaretz, Gerald Steinberg, president of the right-wing and pro-Zionist NGO Monitor writes: "All governments have interests and use power to pursue those goals. 
acquire and maintain financial support as foreign governments are disinclined from providing funding, particularly to human rights groups, given such immense restrictions. In fact, this law explicitly exempts the World Zionist Organization, the Jewish Agency, the United Israel Appeal, the Jewish National Fund and their subsidiary institutions from its stipulations. Hence, it disproportionately affects Palestinian civil society groups in Israel and those NGOs advocating for Palestinian rights as they do not usually receive Israeli governmental funding and depend on foreign financial support. Instead, and despite directly contravening principles of international law, Jewish-Israeli settler organizations are privately funded, and state-sponsored, thus remaining unaffected by the new regulations.

\section{vi. The Ban on Boycotts Law}

Passed on July 11, 2011, The Bill to Prohibit Imposing a Boycott Law (2010) prevents any initiatives by Israeli citizens and residents encouraging or enabling any form of boycott against Israeli institutions, organizations, citizens or goods. Taking the wind out of the sails of any possible discussion, the law enables "any injured party" with the power to sue any individual or institution that advocate a boycott against them, without even having to supply evidence for the damage sustained..$^{15}$ Should the Israeli

When officials from Sweden, Switzerland, Denmark, Norway, and another dozen nations use their 'soft power' to fund dozens of Israeli groups, such as Breaking the Silence, Yesh Din, and the Public Committee Against Torture in Israel, whose officials travel the world declaring that Israel is a nation of war criminals, these groups are also promoting the interests of their sponsors. .... In election after election, the governments chosen by Israeli voters have differed with European positions. However, by massively funding opposition NGOs, many of which claim to promote human rights (although they do this selectively), Europe tries to interfere with and manipulate the legitimate outcome of Israeli elections." Here Mr. Steinberg seems to imply that by using foreign funding to inform the Israeli public of the human rights and legal violations committed by their government, Israeli NGOs are actually allowing European governments to interfere in internal Israeli politics. The logic adopted by Steinberg, similar to the logic of the law itself, is that any criticism against devastating Israeli government policies is not pursued by the Israeli NGOs out of their own agency, but is the result of manipulation from foreign forces. Ironically, instead of actually challenging the legitimacy of the criticisms and information compiled by Israeli NGOs, Steinberg appears more concerned that informing the Israeli public of the human rights and legal violations committed by their government does have an effect on their willingness to support such policies. See Gerald M. Steinberg, "Transparency for NGOs is not antidemocratic," Haaretz, February 23, 2011, http://www.haaretz.com/print-edition/opinion/ transparency-for-ngos-is-not-anti-democratic-1.345164.

15 Adalah: The Legal Center for Arab Minority Rights in Israel, New Discriminatory Laws. For an analysis of the global movement (launched by Palestinian civil-society organizations in 2005) for boycott, divestment and sanctions against Israel from various perspectives of the campaign, see Wiles (2013). 
courts conclude that a civil wrong was perpetrated, it can order payments in sums of up to 30,000 New Israeli Shekels (NIS) to the 'injured' party in damages. Foreign citizens violating the law could be denied entry into Israel for 10 years. ${ }^{16}$ Important to note is that any boycott against products manufactured in illegal West Bank settlements is also considered an attack on Israeli goods and therefore criminalized under this law. In other words, the illegally occupied lands in the West Bank are here considered part of the state and economic regime of Israel. ${ }^{17}$ Rendering the support or propagation of boycotts an actionable civil wrong, this law effectively prevents many civil society and advocacy groups from engaging in non-violent political actions of this form. Further, it denies both Arab and Jewish citizens and residents of Israel the right to actively and openly refuse to support criminal and other problematic Israeli groups, corporations and institutions fuelling the occupation of Palestinian-owned lands.

\section{vii. Loyalty Oath Bill}

Seeking to extort from Palestinian citizens acceptance of the principle that Israel is a Jewish state, the amendment to The Citizenship Law (1952)

16 Adalah: The Legal Center for Arab Minority Rights in Israel, New Discriminatory Laws.

17 Integration of the Jewish settlements in the West Bank into the Israeli social, legal and territorial corpus was further deepened with two major developments in December 2012. First, after various legal battles, the majority vote of the Council for Higher Education in Judea and Samaria to grant full university status to the Ariel University Center took full effect. This move renders Ariel University Center Israel's eighth accredited university and includes a gradual increase of the institution's annual government funding. As the fourth largest illegal Jewish settlement in the West Bank, Ariel interrupts the territorial integrity of any future Palestinian State based on the pre- 1967 borders, as it blocks access between major Palestinian towns in the south and those villages to the north of the settlement. Yet, despite this territorial reality, Prime Minister Netanyahu stated that "Ariel is an inseparable part of Israel and it will remain that way under any future agreement." Moreover, in what most observers identified as a response to the United Nations approval of the Palestinian bid for non-member observer state status, the Israeli government officially agreed to the building of 3,000 housing units in the contentious area known as E1; an area of the West Bank that runs between and connects the easternmost edge of annexed east Jerusalem to the mega-settlement of Ma'aleh Adumim. Building in this area would create a large block of contiguous Israeli settlements effectively slicing the West Bank into a northern and southern part, and would limit travel to Ramallah and Bethlehem to only narrow corridors around Ma'ale Adumim - far from the Old City and Jerusalem. See Barak Ravid, "Israel's cabinet votes to recognize Ariel college as accredited university," Haaretz, September 9, 2012, http://www.haaretz.com/news/national/israel-s-cabinet-votes-to -recognize-ariel-college-as-accredited-university-1.463690;AlJazeera English, "Israel rejects outcry over settlement plan," December 04, 2012, http://www.aljazeera.com/news/middle east/2012/12/2012123101816967394.html; Jerusalem Post, "Israel okays building of 3,000 units in Jerusalem, W. Bank," November 30, 2012, http://www.jpost.com/DiplomacyAnd Politics/Article.aspx?id=294118. 
imposes a loyalty oath for non-Jewish persons seeking naturalization in Israel and for Israeli citizens seeking first ID cards (obligatory at the age of sixteen). Having received government approval on October 10, 2010 (but not a Knesset majority as of yet) the proposed amendment to The Citizenship Law (1952) requires the declaration of a loyalty oath to Israel as a "Jewish, Zionist, and democratic state, to its symbols and values, and to serve the state in any way demanded, through military service or alternative service, as defined by law."18 This wording is a substantial change from the phrasing of the current declaration: "I declare that I will be a loyal citizen of the State of Israel." ${ }^{19}$ As evident, the legal imposition of a declaration identifying Israel as a state for Jews only, not only targets the historical ties of Arab citizens to the land, but it also reinforces existing sentiments of alienation within the community. Moreover, the bill also targets the non-Jewish spouses of Israeli citizens who, as non-Jews, will be obliged to swear the oath in order to live with their partners.

All in all, three important observations surface from these laws. The first point is that these laws are pervasive. They target all areas of Arab life in Israel: land rights, economic, land and budgetary allocations, freedom of association and expression, the right to protest and challenge Zionist policies, and even the right to ask for equality in the law, among other areas. Important to note is that these legal amendments are not made in isolation but against the background of a hegemonic Zionist discourse. The aim here is to force concession to a dominant Zionist consensus on the Arab citizenry (Rouhana and Sultany 2003). The second point about these legal amendments is that, if we pay attention, we will notice that some of the most controversial initiatives are amendments to existing legislation that was created in the first few years of (or prior to) the establishment of the state. For instance, from the limited selection of laws

18 Adalah: The Legal Center for Arab Minority Rights in Israel, New Discriminatory Laws. Israeli Labour Ministers submitted a draft of an alternative loyalty oath based on "the liberal and open spirit of Israel's declaration of independence." According to this draft, prospective citizens would be required to swear an oath to be "a citizen loyal to the State of Israel as a Jewish and democratic state, in the spirit of the declaration of independence, and ... committed to honouring the laws of the state." Here, the word 'Zionist' is left out. See Haaretz, "Barak drafts alternative loyalty oath, based on liberal spirit' of Israel," October 17, 2010, http://www.haaretz.com/news/national/barak-drafts-alternative-loyalty-oath-based -on-liberal-spirit-of-israel-1.317701. The fact that Prime Minister Benjamin Netanyahu also supported the draft citizenship loyalty oath quickly indicated to Labour coalition members that the passing of the law would result in a payoff in the form of a settlement building freeze. This did not happen.

19 Adalah: The Legal Center for Arab Minority Rights in Israel, New Discriminatory Laws, 18. 
mentioned above, there is a British Mandate-era law from 1943, The Independence Day Law of 1949, and The Citizenship Law of $195^{2}$ that are being amended. So, these are some of Israel's oldest laws. These laws serve as a foundation of the State of Israel and have been part and parcel of the shaping of its identity, dynamics, and attitudes. In fact, as mentioned, The Citizenship Law (1952) is one of the most important laws in Israel because as an extension The Law of Return (1950), it is a key tool for ensuring a Jewish demographic majority. As such, the kind of obtrusive, discriminatory, and aggressive legislation passed by today's Knesset does not only depict an intensified right-wing trend in Israeli society and politics. It also depicts a change in the identity and disposition of the state itself. What this shows is that, for its self-preservation, the Israeli regime requires a constant and ongoing (re)creation of itself in opposition and response to its Palestinian-Arab citizenry. In effect, every moment of preservation of Israel's exclusionary regime requires as much energy as its establishment. ${ }^{20}$ Finally, the third (and rather obvious) point that arises from an examination of this legislation is that the strengthening of the Jewish character of the State of Israel inevitably generates a feeble and tenuous democratic character. The political regime in Israel did not amend the discriminatory Law of Return (1950) for Jews. Seeking Jewish political and demographic dominance, it instead amended The Citizenship Law (1952) for Palestinians. ${ }^{21}$ As a result, this wave of new legislation shows that Jewish ascendancy is antithetical to principles of democratic citizenship and equality.

\section{Formal and Declarative Levels}

Jewish dominance is both concrete and irrefutable. Established in 1948, Israel was declared to be a Jewish state. The legally entrenched definition of Israel as 'the state of the Jewish people' or a Jewish state provokes and fuels the multiple forms of discrimination that pervade every sphere of Palestinian existence. Visible symbols such as official state holidays, the flag and other state symbols, the national anthem, the imposition of religious observances, street and road signs depicting the names of villages and towns and regulated dietary laws are all built upon the premise of the social and political hegemony of the Jewish people, and completely dismissive of the Palestinian citizenry (Ghanem 1998, 432). When it comes to

\footnotetext{
20 See Voegeli (2009). This author keeps a copy of this paper in her personal records.

21 For a good discussion on these laws, see Cook (2006, Chs. 1 and 3$)$.
} 
language rights, although Arabic is also an officially recognized language, the Hebrew language is dominant in all spheres of Israeli society. This was intensified in 2009 where the Transportation Minister announced the Hebraization of all major road signs in Israel whereby the Arabic names of cities, towns and villages would be replaced with its Hebrew name but in Arabic script. ${ }^{22}$ Here, to the non-Arabic speaker viewing the Arabic letters, Jewish ascendancy and the political project of the Hebraization of Israeli society is painted as an apparent symbol of tolerance, inclusion and coexistence. Other than private-sphere events and immediate community surroundings, Arabic speakers have limited state-affiliated means for the development and exercise of their language. Indeed, the status of Arabic is so inferior to that of Hebrew that government institutions and even entire Ministries often turn down official documents in Arabic and request a notarized Hebrew translator. In fact, in a recent publication titled The Inequality Report (2011), Adalah states:

$[\mathrm{M}]$ ore than 200 major principle decisions issued by the Supreme Court have been translated into English and have been published on the court's website along with the original Hebrew decisions. Although the majority of these decisions are relevant to Palestinians in the OPT, none of them has been translated into Arabic. ${ }^{23}$

Further, while several laws are implemented to promote and preserve Jewish culture and create Jewish cultural institutions, such as The High Institution for Hebrew Language Law (1973) among others, no such law exists which refers to Palestinian-Arab culture, history, or heritage. ${ }^{24}$ As a result, Jews are provided legally enshrined rights both as a collective and as individual citizens, whereas Arab citizens of Israel lack a clear and official legal and formal status in Israel as a collective, and fail to identify with the intrinsically Jewish and Zionist symbols of the state at an individual level.

22 For instance, "Al Quds" - the Arabic name for Jerusalem - would become "Yerushalaim," but written out in Arabic letters. In The Inequality Report, Adalah: The Legal Center for Arab Minority Rights in Israel draws the readers attention to the Supreme Court's decision in HCJ 4112/99, Adalah, et al. v. The Municipality of Tel Aviv-Jaffa, et al., rendered on July 25, 2002, by Justice Dalia Dorner. Submitted by Adalah together with the Association for Civil Rights in Israel, this case referred to the lack of Arabic text on traffic, warning, road and other informational signs in the mixed Arab-Jewish cities of Tel Aviv-Jaffa, Ramla, Lydd, Acre, and Nazareth Illit (Upper Nazareth), and requested its modification.

23 Ibid., 46.

24 See Adalah: The Legal Center for Arab Minority Rights in Israel, "Additional Information to the UN CERD Committee in Response to the List of Issues Presented to Israel," February 2007, http://www.old-adalah.org/eng/intlo7/adalah-cerd-febo7.pdf. 
Inequality in Israel is manifested in various concrete ways. Social rifts in Israel exist among women and men, Mizrahi, or Eastern Jews, and the dominant Ashkenazi, or Western Jews, Orthodox versus secular Jews, Israel-born Jews (Sabar) and new Jewish immigrants (Olim), along with other dividing lines that are based on class, political expression, physical handicap, sexual orientation and gender, and area of residence. ${ }^{25}$ Granted, Israel has instituted some of the most progressive and tangible legislation and policies targeting these forms of disenfranchisement and division. Yet, as Adalah points out:

Israel's Knesset, for example, has legislated strong anti-discrimination legislation and legal protections for women and disabled persons. However, the same has not been done for the Palestinian minority in Israel. As a result, Palestinians who are also members of other marginalized groups do not receive the full benefit of such protections. ${ }^{26}$

Despite forming over 20 percent of the total population of Israel, Palestinian-Arabs are not recognized as a national group or minority in The Basic Laws of Israel. For the most part, the Arab citizenry is viewed as a threat, and often explicitly referred to as a 'fifth column', 'security concern', or 'demographic time bomb' by Israeli politicians and public figures. As a national non-immigrant collective forming a demographic minority on its historical lands, Palestinian-Arabs are not treated as an underdeveloped or marginalized community by the state. Instead, Palestinian citizens are confronted with intricate racialized policies of exclusion which, allied with partial inclusion in all spheres of life, only further the existing gaps between the Jewish majority and the Arab minority. These policies fuel and are fuelled by the absence of a provision in Israeli law for the concept of constitutional equality. Now, a promise of full equality for all citizens is made in the Declaration of the Establishment of the State of Israel, its Declaration of Independence, yet it is thoroughly absent in the form of actual legislation. Equality is not an enshrined constitutional right, and is absent from The Basic Law: Human Dignity and Freedom which has, in the absence of a written constitution, served as Israel's constitutional bill of rights since 1992. Hence, while the law protects the equal rights of

25 Adalah: The Legal Center for Arab Minority Rights in Israel, The Inequality Report, 4.

26 The Women's Equal Right's Law (1951) and The Equal Rights for People with Disabilities Law (1998) are examples of such legislation. Further, on March 30, 2011, the Knesset approved The Expansion of Adequate Representation of Women (Amendments) Law, 57712011 which requires adequate representation of women in posts of commissions of inquiry according to The Commissions of Inquiry Law, 5729-1968 and The Government Law, 57612001 (ibid., 5, 59). 
disadvantaged groups, no general statute relates to the right to equality or freedom from discrimination for all citizens. ${ }^{27}$ As noted by Adalah:

While Supreme Court Justices have interpreted The Basic Law: Human Dignity and Liberty as comprising the principle of equality, this fundamental right is currently protected by judicial interpretation alone. .... The absence of an explicit guarantee of the right to equality in the Basic Laws or ordinary statute diminishes the power of this right and leaves the Palestinian minority in Israel vulnerable to direct and indirect discrimination. ${ }^{28}$

On this point, recent observations on Israeli civic rights submitted by the United Nations Human Rights Committee in July 2010 stressed that "the State party's Basic Law: Human Dignity and Liberty (1992), which serves as Israel's bill of rights does not contain a general provision for equality and non-discrimination." ${ }^{29}$ And they move on to argue that Israel "should amend its Basic Laws and other legislation to include the principle of nondiscrimination and ensure that allegations of discrimination brought before its domestic courts are promptly addressed and implemented."30

The lack of an explicit guarantee and protection of the right to equality is rooted in the declared Jewish character of the state. In fact, although the definition of the Israeli state is continually contested, movements within Israel to amend the wording of The Basic Laws since 1985 so that the State of Israel is "the state of its citizens" or "the state of the Jewish people and its Arab citizens" have consistently been voted down by Israeli Knesset members. ${ }^{31}$ The self-definition of Israel as a Jewish state is most tangibly and indisputably revealed in and maintained through the two key

27 For more on the absence of legal assurances of equality, see Masalha (1993).

28 Adalah: The Legal Center for Arab Minority Rights in Israel, Inequality Report, 14. Emphasis added.

${ }^{29}$ See United Nations Human Rights Committee, Ninety-ninth session, Consideration of reports submitted by States parties under article 40 of the Covenant: Concluding observations of the Human Rights Committee-Israel, (CCPR/C/ISR/CO/3), July 29, 2010, Section C, Point 6, http://www2.ohchr.org/english/bodies/hrc/docs/CCPR.C.ISR.CO.3.doc, retrieved from Adalah: The Legal Center for Arab Minority Rights in Israel, The Inequality Report, 14. Emphasis added.

${ }^{30}$ Ibid. Emphasis added.

31 For years, Knesset members have rejected, again and again, bills proposed by Arab MKs and political representatives that are aimed at meeting the needs and improving the socio-legal conditions of the Arab community. Whether explicitly asking for universal equality for all citizens or addressing inequalities in the allocation of funds in the areas of education, culture and art, or the inclusion of Arabs in sporting organizations, societies and unions, such bills are consistently voted down. For a detailed account of this ordeal since 2002, see Sultany (2003), (2004) and (2005). See also Mtanes Shihadeh, Israel and the Palestinian Minority: Political Monitoring Reports (Haifa, Israel: Mada al-Carmel: Arab 
nationality and immigration laws mentioned above: The Law of Return (1950) and The Citizenship Law (1952). As a settler movement seeking out a territory for immigration and colonization, Zionist bodies aimed at creating a relatively homogenous Jewish settler-immigrant population in Palestine. Resulting from this Judaization project were socio-political and legal policies that foster pervasive discrimination against non-Jewish citizens, and which challenge the tenets of democratic citizenship. One such law, and perhaps the most important legal expression of Israel's selfdefinition as a Jewish state, The Law of Return (1950), guarantees the right of immigration to every Jewish person. Instead of a general civic immigration law, The Law of Return (1950) only applies to any Jew looking to immigrate to Israel, to her/his spouse, children, grandchildren, and their respective spouses. And it applies to Jewish immigrants after the establishment of Israel and retroactively to Jews, without major preconditions, who had immigrated to Palestine or had been born there before the creation of the State. However, Palestinian refugees who were expelled from their land and homes in 1948 are not granted the 'right of return' and not even entitled to residency or citizenship status. An extension of The Law of Return (1950) is The Citizenship Law (1952) which grants automatic Israeli citizenship to any Jew upon immigration "according to the Law of Return" without any length of residency, economic or language requirement. In essence, a nation-state with a hierarchical citizenship regime is established through this legal tenet encompassing all Jews, and only Jews, by virtue of their ethno-national or religious descent. This law solidifies the secondary citizenship status of Palestinian-Arabs, as there is no chance for a non-Jew to acquire automatic citizenship through the Ministry of Interior. Indeed, even partners of Palestinian-Arab citizens of Israel can only gain citizenship or residency status through extensive legal procedures. Evidently, these same two laws, each of which is both ideologically and historically foundational to the State of Israel, privilege Jews by systematically excluding Palestinian-Arabs who were compelled to flee their villages and homes between $1947^{-1952}$, deny them their indigenous status, strip them of their right to their land and directly contradict the internationally-recognized Palestinian right of return as affirmed in UN Resolution 194. Together, The Law of Return (1950) and The Citizenship Law (1952) form the substructure upon which a whole arrangement of formal policies,

Center for Applied Social Research) Quarterly PDF e-publications, http://mada-research .org/en/political-monitoring-report/. 
informal practices and new legislation ensuring Jewish dominance within the State of Israel, are based. ${ }^{32}$

\section{Structural and Institutional Levels}

Arab citizens of Israel are involuntarily excluded from a wide range of Israeli institutions, public decision-making and civil power centres, including all areas of the legislative, executive, judiciary and government administration. To begin with, Arabs are excluded from the political-decision making centres. The Arab parties that are anti-Zionist or non-Zionist have historically played the role of a 'permanent opposition'. As it stands, no Arab political party has been part of a ruling government coalition..$^{33}$ This exclusion is fuelled both by the refusal of other coalition members to include Arab political parties and by opposition of Arab parties to the political mandate of these coalitions. Moreover, Arab political representatives have systematically been excluded from the important Knesset committees, such as the Department of Finance, Foreign Affairs, and Defence. In fact, since its inception, Israel has only had a few ministerial positions appointed to its Arab citizenry: Nawaf Massalha was chosen as Deputy Minister of Foreign Affairs in 1999, Salah Tarif was 'Minister without portfolio' in 2001, and Raleb Majadele was Minister for Science and Technology in 2007. In Israel, the legislative branch is represented by the Knesset and has sole authority to enact laws. In the absence of a constitution, the Knesset acts as both the legislature and constituent assembly and enacts a series of Basic Laws to fill the constitutional void in the state. ${ }^{34}$ As per the

32 In addition, on July 1, 2008, the Knesset voted to extend the validity of The Citizenship and Entry into Israel Law (2003) for another year to July 31, 2009. Although the law is defined as a "temporary order" it has been extended nine times to date. First enacted in July 2003, the law denies Palestinian citizens the right to acquire residency or citizenship status in Israel for their Palestinian spouses from the OPT entirely on the basis of their nationality. Since its inception, changes have been made to this legislation that add to its racialized structure. Amendments were introduced to the law in July 2005 which allowed family unification in very restricted and limited conditions, thus inflicting immense violations of rights protected by international law, mainly the rights to family life, privacy, dignity, marriage, and equality. In May 2006, the Israeli Supreme Court once again displayed its complicity in legitimating Israel's racialized and discriminatory legal system by upholding the constitutionality of a law that denies a person's basic rights to humanitarian connections (e.g. the right to family ties) on the grounds of her/his national belonging. See Adalah: The Legal Center for Arab Minority Rights in Israel, The Inequality Report for more.

33 Ibid., 52 .

34 In Citizens without Citizenship, Nimer Sultany explains: "In addition to functioning as the legislature and constituent assembly, the Knesset fills a quasi-juridical role. An example of this function is the immunity granted to MKs and the power granted to the Knesset to remove the president of the state and the state comptroller from their positions" $(2003,17)$. 
recent 2013 elections, the United Arab List and the Arab Movement for Change (Ra'am-Ta'al), the National Democratic Assembly (NDA-Balad), and the Democratic Front for Peace and Equality (Al-Jabha/Hadash) are the main Arab political parties (or parties with a majority of Arab members) in the Knesset, holding 11 of the available 120 seats. In the previous eighteenth Knesset, only one of the members, Haneen Zoabi, was an Arab woman representative, and though not the first Arab woman to enter the Knesset, Zoabi is the first to be elected for an Arab political party. ${ }^{35}$

When it comes to the judiciary, the Israeli Supreme Court is the highestlevel of the court system. Often celebrated as a force of liberal-democracy and rule of law that, in the context of the 'war on terror', fights terrorism within the parameters of the law, the rulings of the Supreme Court are binding on every court in Israel. However, this perception of the Supreme Court is rather distanced from the political realities of the multifaceted system of control and expulsion established by the state. In fact, whether it is the depiction of the State of Israel as a democratic system struggling for recognition, survival and coexistence within the framework of the law, the defence of the Israeli military as a governmental force that recognizes and respects the laws of warfare, or the portrayal of the iron-fisted Israeli occupation regime in the Gaza Strip as continuing to provide necessary amounts of fuel, electricity and goods required to satisfy the vital humanitarian needs of the besieged civilian population, ${ }^{36}$ the Supreme Court has - to a great degree - assumed the official position of the state. ${ }^{37}$ In other words, the rulings of the Supreme Court espouse the liberal-Zionist belief that Israel is able to maintain a genuine democratic order within its 1948-boundaries while simultaneously (re)producing an oppressive and

35 During the 2013 elections, Zoabi was joined in the election race for the nineteenth Knesset by three other Arab women, Nabila Espanioly of the Hadash party, Asma Aghbarieh-Zahalka of the joint Jewish-Arab Da'am Workers Party, and Nadia Hilou of the Labour Party. The Knesset has lists of its members according to their parliamentary party readily available in English, see http://www.knesset.gov.il/mk/eng/mkindex_current_eng .asp?view=1.

36 Disturbingly, Israel has even gone so far as to consider at an official level to monitor the food consumption of the Gazan population by calculating a minimum number of 2,279 calories required to keep Gazans from starvation. See United Nations News Centre, "UN agencies join in shared call for end to Israeli blockade of Gaza," June 14, 2012, http://www .un.org/apps/news/story.asp?NewsID=42227\#.ULN5QU-er-k; Amira Hass, "2,279 calories per person: How Israel made sure Gaza didn't starve,” Haaretz, October 17, 2012, http:// www.haaretz.com/news/diplomacy-defense/2-279-calories-per-person-how-israel-made -sure-gaza-didn-t-starve.premium-1.470419?localLinksEnabled=false.

37 For example, see High Court of Justice Lawsuit 9132/07,Jaber al-Bassiouni Ahmed and Others $v$. The Prime Minister, decision delivered January 30, 2008, Paragraph 21-22, http:// elyon1.court.gov.il/files_eng/o7/320/o91/n25/o7091320.n25.htm. 
multifaceted system of control and expulsion outside this area. ${ }^{38}$ For the most part, as in the other arenas of Israeli public and civic life, the presence of Arab citizens on the Supreme Court has been extremely minimal. Only two Arab male justices have served in the Court, Abd-er-Rahman Zoabi in 1999, and Justice Salim Joubran who has been serving since 2003 and today remains the only Arab justice out of a total of 15 Supreme Court justices. All in all, Arabs are systematically denied employment in senior positions in Israeli society and government, and are excluded from the centres of public, social, economic and military power. ${ }^{39}$ At the same time, special Israeli institutions have been created and assigned the specific task of dealing with Arab affairs and policy-making. ${ }^{40}$ And, for the most part, these committees view Arab citizens through a security lens and highlight the potential security risks allegedly associated with the ethnic, national and religious identities of the Arab community. Indeed, explicit expression of distaste and contempt for Palestinian-Arabs in Israel is not uncommon among academic, journalistic, political and religious figures in Israeli society. Too many to list here, it is suffice to say that contrary to common

38 On this point, see Sultany (2007).

39 In August 2012, the Netanyahu-Lieberman administration discussed reforming Israel's draft law, The Tal Law, which deals with the special exemption from mandatory service in the Israeli military given to ultra-Orthodox Jews and Arab citizens. In the past, Arab citizens could volunteer for different forms of national service. In fact, the number of Arab youth choosing to perform national service increased by 60 percent from 2011 to 2012, reaching 2,400 Arab volunteers. Under the new law, national service would be compulsory in a range of social service and health-care institutions, including schools, cultural and community centres and hospitals. Theoretically, such national service could then also qualify Arab citizens to the benefits provided to those Jewish-Israelis performing military service, such as access to scholarships, reduced mortgages, financial aid and accommodation at Israeli universities, among others. However, as it stands, major Arab parties and most Arab civil society leaders oppose compulsory civilian national service for Arab youths, viewing it as a stepping stone for future legislation imposing compulsory military service on the population. Many argue that until Israel becomes 'a state for all its citizens' and begins to seriously implement policies and practices placing Arab citizens on equal footing with their Jewish counterparts, compulsory national service further violates and infringes upon the rights and legitimate demands of the Arab citizenry. See Meirav Arlosoroff, "National Service official: Israeli Arabs are more pragmatic than their leaders," Haaretz, June 27, 2012, http://www.haaretz.com/business/national-service-official-israeli -arabs-are-more-pragmatic-than-their-leaders-1.444263.

40 For instance, the General Security Services (GSS; Sherut haBitachon haKlali), known outside the country as the Israeli Security Agency or Shin Bet is believed to have three operational wings divided into Arab Affairs, Non-Arab Affairs and Protective Security Department. Monitoring and repression of Israel's Arab citizenry is often incorporated in the mandate of the Arab Affairs Department of the GSS. See BBC News, "Profile: Israel's Shin Bet agency," January 30, 2002, http://news.bbc.co.uk/2/hi/middle_east/1791564.stm; Sultany (2004, 76-77). 
perception, such pronouncements are not limited to the extreme rightwing elements of Israeli society but are deeply entrenched in the mainstream consciousness. ${ }^{41}$

From the period of the Al-Aqsa Intifada there has been a marked intensification of state-led attempts to delegitimize its Arab citizenry. Here, the campaign of delegitimization of Palestinian-Arab political representatives and, more recently, of Arab civil society organizations in Israel has been particularly fierce. Since the Nakba, Palestinians have become a strategic obstacle to the goals of the Zionist movement and its ongoing Judaization project, thus rendering it impossible for this population to form a genuine and active part of Israeli society. As a result, the Palestinians in Israel find themselves on the double periphery of both Palestinian and Israeli political institutions and their respective (and intertwined) national movements. Yet, despite their marginality, this community is playing an increasingly important political role in the development of the ZionistPalestinian conflict. They continue to point to the social and political transformations within Palestinian society in Israel since the forceful dispersion of their national group, and expose the inherent racial discrimination and contradictions in Israeli practices and policies.

Overall, consecutive Israeli governments have adopted one main strategy for the suppression of Arab political participation, expression and association: relocating political initiatives by Arab citizens to the realm of prohibited action. The criminalization of Arab political action and expression concerning the topics of national identity, belonging, rights and membership was done by Israel during the period of the first and second Intifadas, and reappears on commemorations held on Nakba Day (May 15) and Land Day (March 30), as well as at political gatherings and activities held opposing the demolition of homes, discriminatory legislation, and military attacks against Palestinians in the West Bank, Gaza Strip, and the neighbouring Arab states. As shown below, the suppression of political activity is particularly heightened in times of military conflict and political and national turmoil when the perspectives of much of the Arab citizenry run counter to the hegemonic Zionist discourse of security, self-defence and Jewish domination. And here common tactics such as the use of arrests, detention, interrogation and surveillance are employed by the Israeli security apparatus to silence dissent.

41 For detailed accounts of racist and discriminatory remarks against Arabs in Israel see Sultany (2004, 60-61) and (2005, 77-89, 137-139, 143-163), along with Mada al-Carmel's online quarterly Political Monitoring Reports. 


\section{Mass Protests of October 2000}

The Al-Aqsa Intifada began on September 28, 2000 after Ariel Sharon's provocative visit to Haram al-Sharif, the site of Al-Aqsa mosque, sparked mass demonstrations in the OPT. The violent suppression by the entirety of the Israeli security apparatus resulted in many Palestinian deaths and injuries, and led to a set of demonstrations inside Israel by Palestinians, which were severely repressed in early October 2000. Mass demonstrations among Palestinian citizens throughout Northern Israel were immediately met with violence by the Israeli police in the form of live ammunition, rubber-coated steel bullets and tear gas, resulting in the death of ten Palestinians in the course of three days. By the end of ten days of violence, thirteen Palestinian citizens of Israel had been killed, hundreds injured, and more than one-thousand arrested by Israeli police. ${ }^{42}$ Over the course of the next few months, human rights organizations reported trends of arbitrary arrest and detention, as well as inhumane treatment by Israel of Palestinians in custody. For months after the demonstrations had ended, the police continued to arrest Arab citizens, many of whom were held without bail, denied legal counsel, and forced into making false confessions. Israel's response to the deaths of thirteen of its Palestinian citizens in October 2000 was immensely hesitant, and led to the Or Commission of Inquiry on September 29, 2000 to investigate the October clashes. ${ }^{43}$ In the end, testimonies given before the Commission by police officers and commanders, as well as Palestinian citizens and community leaders consistently confirmed that the Palestinian demonstrators were unarmed and posed no threat to the lives of the Israeli security forces present; that Israeli police provided inadequate protection for Palestinian citizens under attack from Jewish vigilantes and mobs; and that the use of physical force, beatings and live ammunition by the police was widespread and indiscriminate. ${ }^{44}$ Yet, and as Adalah explains:

42 Adalah: The Legal Center for Arab Minority Rights in Israel, Inequality Report, 55 .

43 The official title was the "State Commission of Inquiry into the Clashes between Security Forces and Israeli Citizens in October 2000."

44 There are, however, numerous criticisms to be made against this Commission including its problematic depiction of Arab protesters, implication of Arab culpability and failure to reprimand and even absolving Israeli security officials and political leaders, failure to include Ariel Sharon's provocative visit to the Al-Aqsa Mosque as part of the investigation, and the language it has adopted throughout the report, among others. All of this places the objectivity and intention of the inquiry into question. For a detailed account of the criticisms posed against the Commission, see Sultany $\left(2004,85^{-90}\right)$. 
Contrary to the recommendations of the official Or Commission of Inquiry [presented] in 2003, in January 2008, the Attorney General decided to close the files and not to issue a single indictment against anyone responsible for the killings. Until today, ten years after the killings, no police officer, commander or political leader has been held accountable for the deaths. ${ }^{45}$

As a result of the October 2000 protests, Palestinian citizens paid a high economic cost. Businesses suffered tremendously during September and October when many Palestinian shop owners participated in a general strike to protest Israeli aggression. In addition to the economic costs, there was an immeasurable psychological toll living in an increasingly polarized and tense society. Surfacing with the events of October 2000 and the Or Commission, and confirmed by the political encounters that followed and are explained below, Palestinians inside Israel continue to be defined as a 'security threat' and an 'internal enemy' by the state.

\section{Acre Riots of 2008}

On the night of Yom Kippur, the Jewish Halacha (body of religious laws) instructs religious Jews to fast and abstain from most activity, including driving. While driving is not legally prohibited on this day, and instead only shops and recreational institutions are required to be closed, secular Jews and Palestinian-Arabs are nevertheless unable to act otherwise. As a result, residents of so-called 'mixed cities' like Acre undergo a type of curfew on Yom Kippur. On October 8, 2008, Tawfiq al-Jamel, an Arab resident of Acre drove with his teenage son and family friend to pick up his daughter from one of the mixed areas in the city. Upon entering the mixed area, a group of Jewish youth pelted their car with stones claiming he had violated the religious laws for that day. Al-Jamel and his son sought sanctuary in the home of a relative as a mob of Jews gathered outside threatening the family and chanting "death to the Arabs." Once news spread of the family's besiegement, hundreds of Arab youths gathered to come to their assistance in the Old City and marched to the city centre, smashing shop windows along the way in a display of anger. In subsequent days, Jewish gangs roamed Acre's streets, torched several Arab homes, and forced dozens of Palestinian-Arab families living in Jewish-dominated areas around Acre to flee.

The Acre riots lasted for just under a week and were yet another in a line of incidents that showed the state's policy of systematic discrimination

45 Adalah: The Legal Center for Arab Minority Rights in Israel, The Inequality Report, 55. 
against Palestinian citizens. While Israeli leaders tried to calm the tensions by appealing to the idea of coexistence, rather than denouncing the Jewish culprits, they argued that Acre's Arab residents provoked the attacks. Moreover, Israeli border guards were pulled from the Ramallah area of the West Bank and sent to Acre to quell the riots, and the residents of the mixed cities of Haifa, Jaffa, Ramla, Lydd and Wadi Ara also experienced increased police presence. ${ }^{46}$ Taken together, the aftermath of the Acre riots and the State's reaction was testimony to the security lens through which the Israeli government views Palestinian citizens. In the end, after three days of rioting and clashes, the Israeli police arrested fiftyfour residents, about half of them Jews and half Arabs. Yet, despite an acknowledgment by the Northern District Police commander stationed in the area during the riots that "Jews were the dominant factor in the breach of the peace in Acre," most of the arrested Jewish youth were released while the reprimand of many Arab youths was extended. ${ }^{47}$ Further, on October 13, 2009 the Israeli daily newspaper Haaretz reported that the Minister of Public Security and the Police Commissioner had decided to create a special secret unit to monitor the Arab population. Called the mistaravim unit, Jewish officers in this unit go "deep undercover" in Arab areas including East Jerusalem and the adjacent Arab villages. ${ }^{48}$ Though the official statement holds that the main purpose of the undercover unit is to monitor criminal activities, it is evident that its placement in predominantly Arab areas not only places the community within a security lens, but also enables the monitoring of their political activity.

\section{The 2008-20o9 War on Gaza}

On 27 December 2008, Israel initiated "Operation Cast Lead," an extensive military offensive in the Gaza Strip consisting of around twenty-three days

46 Ahiya Raved, “Akko Riots: Police ordered on heightened alert," Ynet News, October 10, 2008, http://www.ynet.co.il/english/articles/o,7340,L-3607159,oo.html; Ma'an News Agency, "Israeli border guards pulled from West Bank, sent to quell Acre riots," October 12, 2008, http://www.maannews.net/eng/ViewDetails.aspx?ID=205596.

47 See Mtanes Shihadeh, "Israel and the Palestinian Minority: Bi-monthly Monitoring Report of Mada al-Carmel," Jadal, no. 1 (January 2009), http://mada-research.org/ en/2009/01/08/jadal-issue-1-january-2009/.

48 "Mistaravim" is a Hebrew term, referring to Jewish police officers who go undercover among the Arab population. See Tomer Zarchin, "Secret police unit monitoring Israeli citizens," Haaretz, October 13, 2009. http://www.haaretz.com/print-edition/news/secret -police-unit-monitoring-israeli-citizens-1.6196; Jack Khoury, "Israeli Arab MK: Undercover unit proves police see us as threat," Haaretz, October 13, 2009, http://www.haaretz.com/ news/israeli-arab-mk-undercover-unit-proves-police-see-us-as-threat-1.6177. 
of bombings and shelling from the land, air and sea causing unprecedented damage and injury to the Palestinian civilian population..$^{49}$ Israel's onslaught in Gaza raised the international profile of the plight of the Palestinian people and inspired a massive outburst of global solidarity. Millions of people around the world expressed their outrage through mass demonstrations, sit-ins, occupations, writing campaigns, media statements, and various other actions. Similar to the countless voices on the streets of cities around the world, hundreds of Palestinian citizens of Israel came out into the streets to demonstrate against the Israeli military operation and demand its cessation. Responding to these protests, the police and the General Security Services (GSS), deemed them a threat to the security of the state and collaborated with the judiciary and some Israeli academic institutions to systematically suppress political expression via arrest and detention. Hundreds of protesters were arrested for their mere presence at these gatherings and were sanctioned en masse by the judiciary. Indictments made by the State prosecutor's office were on the grounds of "participating in prohibited gatherings, disturbing the peace and attacking a police officer," and even argued that "the protests are detrimental to the public morale." Similar to the treatment of demonstrators during the October 2000 protests, the judicial courts ignored the fundamental principle of individual examination in criminal cases and resorted to the mass arrest of suspects. At the same time, dozens of police units were invited to academic institutions such as Haifa University to violently disperse political initiatives and vigils organized by Arab students on university campuses. In the end, over 830 demonstrators were arrested

49 Israel violated its ceasefire with the Palestinian political organization Hamas on November 4, 2008 and launched 'Operation Cast Lead' between December 27, 2008 to January 28, 2009. Its intense bombardment of Gaza resulted in around 1,400 Palestinian deaths (over one-fifth of whom were children) and thirteen Israeli deaths - all along with intense destruction of homes and other infrastructure in Gaza as well as brutal violations of Palestinian human rights. Four of the 13 Israeli casualties were a result of friendly fire. As recently as November 4,2012 , Israel was once again the party to break the ceasefire with Hamas and went on to launch 'Operation Pillar of Defence' in the Gaza Strip. Between November 14 to 21, 2012, bombardment of Gaza resulted in over 150 Palestinian deaths (again, over one-fifth of these deaths were children), with 1000 Palestinian injuries, and with three Israeli casualties. See United Nations General Assembly Human Rights Council, Twelfth Session, Human Rights in Palestine and other Occupied Arab Territories: Report of the United Nations Fact Finding Mission on the Gaza Conflict, (A/HRC/12/48), September 25, 2009, http://www2.ohchr.org/english/bodies/hrcouncil/docs/12session/A-HRC-12-48.pdf; Palestinian Center for Human Rights, "Israeli Offensive on Gaza Stopped Following 8 Days of Attacks," Press Release, November 22, 2012, http://www.pchrgaza.org/portal/en/index .php?option=com_content\&view=article \&id=9044:israeli-offensive-on-gaza-stopped -following-8-days-of-attacks-\&catid=36:pchrpressreleases\&Itemid=194. 
during the attacks on Gaza, 34 percent of whom were minors. On the systematic targeting of Palestinian protesters during this violent crackdown, Adalah notes:

Significantly, not one detainee from the Tel Aviv District, where the majority of Jewish protestors against the war were detained, was remanded until the end of proceedings against them. By contrast, all detainees in the Northern District were detained until the end of proceedings against them, and $94 \%$ in the Jerusalem District, where almost all protestors were Arabs. ${ }^{50}$

\section{Criminalizing Arab Political Participation and Discourse}

A further curtailment of the political rights of Palestinian citizens comes in the form of reducing the rights of their political leadership. To stifle the political legitimacy of the Arab representatives and MKs and bring it in line with the dominant Zionist consensus, consecutive Israeli governments have employed a variety of legal tools, including criminal investigations and proceedings as an instrument for political suppression. The political activity of Arab public figures, civil society, and political representatives has been targeted through three main measures:

i. On May 15, 2002, the Knesset passed Amendment No. 35 to The Basic Law: The Knesset to prevent any candidates list and any person from participating as a candidate in elections to the Knesset if their aims or actions either "explicitly or implicitly" deny or challenge the Jewish and democratic nature of the State of Israel. The defined character of Israel as a Jewish state has three inter-related components, derived from a prominent Supreme Court ruling on a case further discussed below, called Ben-Shalomv. Central Elections Committee for the 12th Knesset (1988). As Sultany points out,

[i]n the leading Supreme Court decision of Ben Shalom, the majority held that the minimal definition of Israel as the state of the Jewish people is based on three elements: a Jewish majority in the state, preferential treatment of Jews over other groups in returning to their state, and preferential reciprocal treatment between the state and Jews in the Disapora. A candidates' list that rejects these elements is prevented from participating in elections. ${ }^{51}$

50 Adalah: The Legal Center for Arab Minority Rights in Israel, The Inequality Report, 56 .

51 Sultany also explains that the majority in the Ben Shalom decision also held that a list that supports a repeal of The Law of Return must be disqualified, and that a list calling for total equality between Arabs and Jews "not only on a personal basis, but also on a national basis" also does not recognize the nature of the State of Israel as a state of the Jewish people (2003, 25-26). 
This means that efforts to secure equal legal and political status for Arabs by highlighting the discriminatory legal and political outcomes of Israel's total bias in favour of its Jewish citizens are outlawed and rendered susceptible to a prison sentence. Importantly, the 2002 amendment includes new grounds for disqualification, namely, "support for an armed struggle of an enemy state or of a terrorist organization against the State of Israel" (Sultany 2003, 25-26). Here, the ambiguity of terms such as "armed struggle" and "terrorist organization," coupled with the characterization of neighbouring Arab and Muslim countries (Afghanistan, Iran, Iraq, Lebanon, Libya, Pakistan, Sudan, Syria and Yemen) and the Gaza Strip as "enemy states" are ambiguous and target the Palestinian citizenry. Indeed, in practice, this legislation is almost exclusively applied to Arab MKs.

ii. On June 30, 2008, the Knesset plenum passed Amendment No. 39 to The Basic Law: The Knesset (Candidate who Unlawfully Stayed in an Enemy State). This amendment restricts the freedom of movement of Arab MKs to neighbouring Arab or Muslim states defined by Israel as 'enemy states'. This prohibition was applied retroactively to Arab MKs and was explicitly developed in the context of visits by Arab MKs, namely former MK Dr. Azmi Bishara, to neighbouring Arab states. Following the approval of the amendment, Knesset member Zevulun Orlev (National UnionNational Religious Party) said: "From today, Arab MKs will have to decide: either the Syrian parliament or the Israeli parliament." ${ }^{\prime 2}$ Incidentally, as noted by Attorney Haneen Na'amnih of Adalah:

The new amendment to the Basic Law constitutes a flagrant violation of the constitutional right to be elected. It also circumvents prior judicial rulings, including the Supreme Court's decision that overturned the decision of the Central Election Committee to disqualify the candidacy of MK Azmi Bishara because of his visits in Syria, his political speeches, and other claims. The Supreme Court's decision emphasized the importance of the constitutional right to run and be elected. ${ }^{53}$

iii. Finally, on April 1, 2009, another amendment was proposed to The Basic Law: The Government Loyalty Oath which posits that upon taking up a ministerial office, all Ministers must make a loyalty oath to the state as a "Jewish, Zionist and democratic state" and to the values and symbols of

52 Amnon Meranda, "Bill banning those who visit enemy states from Knesset duty approved,"YnetNews,June30,2008,http://www.ynetnews.com/articles/o,7340,L-3562284,00 .html.

53 Shihadeh, "Israel and the Palestinian Minority: Mada’s Bi-monthly Report," 5. 
the state. Previous to this amendment, Ministers were only required to pledge an oath to the state. ${ }^{54}$

Taken together, the above legislative amendments alter the parliamentary dynamic in Israel and wholeheartedly deny Arab political representatives the means of addressing the needs and demands of their displaced and marginalized community. But this is not a novel development in the Israeli political scene. In 1985, the The Basic Law: The Knesset was amended by adding Section $7(\mathrm{~A})$ which held that an MK or political party can be prohibited from running in the elections if they demonstrate, through their "aims or actions, expressly or by implication, ... denial of the existence of the State of Israel as the state of the Jewish people; denial of the democratic nature of the Jewish state; [or an] incitement to racism" (Schmidt 2001, 280). As evident, the first clause hinges political participation on the explicit recognition of Israel as a 'state of the Jewish people', thereby providing legal status to the notion that Israel is not a state of all of its citizens, including both Arabs and Jews. During debates held in the Knesset at the time with regards to the first clause of Section 7 (A), former Arab MK Tawfik Toubi stated,

To say today in the law that the State of Israel is the state of the Jewish people, means saying to $16 \% 55$ of the citizens of the State of Israel that they have no state and they are stateless, that the State of Israel is the state only of its Jewish inhabitants, and that Palestinian Arab citizens ... reside and live in it on sufferance and without rights equal to those of Jewish citizens ... (Schmidt 2001, 280).

Indeed, the exclusion of Arabs from political participation that resulted from this amendment became evident in 1988, when the Supreme Court was faced with the issue of how to interpret the first clause of Section 7(A). The case of Ben-Shalom v. Central Elections Committee for the 12th Knesset (1988) elucidates the particular circularity of the Israeli regime at political, structural and discursive levels that obstruct and delimit Palestinian participation and development. On the eve of the 1988 Knesset elections, members of the Israeli right-wing Likud and ultra-nationalist Techiya (Renaissance) Party unsuccessfully petitioned the Central Elections Committee (CEC) of Israel to disqualify the joint Jewish-Arab Progressive List for Peace (PLP). According to the petitioners, the PLP did not satisfy

54 Legislative Bill no. 5/18, proposed on April 1, 2009. See Adalah: The Legal Center for Arab Minority Rights in Israel, The Inequality Report, 54.

55 As mentioned in the Introduction of this book, today the Palestinian citizen population totals around $20.5 \%$ of the total population of Israel. 
the conditions for political participation as outlined in Section $7 \mathrm{~A}$ as its party platform stated that it "will struggle for another Israel, an Israel that is for all of its citizens" (Schmidt 2001, 282). The position of the PLP was that a state defined as Jewish is unable not treat its non-Jewish citizens as equals, and that a democratic state (by any acceptable reading of the term) could not give preference to a specific social group (Peled 1992, 437). For the petitioners and some of the judges on the Supreme Court, this argument is tantamount to negating the character of Israel as the state of the Jewish people. ${ }^{56}$ In the end, though the Court decided by a reluctant majority of $3^{-2}$ to support the decision of the CEC and allow the PLP to participate in the Knesset elections, there was a general consensus among the judges that the rejection of a political party is justified if it rejects the Zionist notion that Israel is a state of the Jewish people. With such an interpretation of Section $7(\mathrm{~A})$, the Court effectively sets a precedent whereby other democratic considerations in a case are rendered secondary to the primary aim of maintaining the exclusive Jewish character of Israel. In the words of Israeli scholar David Kretzmer, the Court's decision implied that,

... on the decidedly fundamental level of identification and belonging there cannot be total equality between Arab and Jew in Israel. The State is the state of the Jews, both those presently resident in the country as well as those resident abroad. Even if the Arabs have equal rights on all other levels the implication is abundantly clear: Israel is not their state (Schmidt 2001, 284; also quoted in Peled 1992, 439).

For the PLP and the Arab political parties today, demanding complete equality between Jews and Arabs in Israel and extending this demand to the national character of the state renders them vulnerable to exclusion from the political process. For our purposes, what is of significance here is that despite the willingness of Arab politicians to pursue constitutional amendments through the parliamentary process, their rejection of the particularistic definition of Israel as 'the state of the Jewish people' necessarily leads to their legal exclusion from the process as a whole. The Israeli regime is legally, politically and conceptually designed and organized in a circular manner so as to make it literally impossible to challenge its particularistic definition as a Jewish state. This circularity cogently surfaces in

56 As Peled explains, it is important to note that the PLP did not demand that The Law of Return be annulled but, rather, that the right of return be extended to also include the Palestinian refugees (ibid., 441). 
the above legal amendments, because they illustrate that access to the Israeli civil and political sphere to challenge this particularistic definition rests upon its necessary, and prior, acceptance. One must affirm, adopt and agree with the definition of Israel as a Jewish, Zionist and democratic state before one can even begin to question it through civil institutions. Before the challenge is considered, it automatically renders itself void. Thus, as significant challenge to the particularistic legal, institutional, and procedural arrangement of the state through formal avenues is rendered impossible, so too is genuine representation of the Palestinian-Arab citizenry within the Israeli regime.

\section{Targeting Arab MKs: From Bishara to Zoabi}

In November 2001, prior to a series of indictments, historically unprecedented parliamentary initiatives were launched to revoke the immunity of former head of the NDA-Balad party, Arab MK Dr. Azmi Bishara. The launch of these indictments in 2003 served as the first instance where an MK was prosecuted for political expression and speech. Having examined the circumstances leading to the end of the Israeli occupation of Southern Lebanon and outlined the daily effects of the Israeli occupation on Palestinian life in a speech in Syria, Bishara was charged under The Prevention of Terrorism Ordinance Law (1948) for allegedly aiding a terrorist organization (namely Hezbollah) and under the Emergency Regulations Foreign Travel Law (1948) for coordinating a series of visits for elderly Arab citizens of Israel seeking to travel to Syria to visit relatives living in refugee camps. ${ }^{57}$ While, in April 2003, the Nazareth Illit District Court unanimously ruled to dismiss the criminal charges against Bishara for his visits to Syria, it nevertheless upheld the indictments against Bishara in November 2003 for his political speeches.

With the partial lifting of a gag order on the investigation against the former MK, it was later revealed in April 2007 that Bishara was specifically accused of aiding the enemy during wartime, passing information on to the enemy and contacts with a foreign agent, including during the 2006 Israeli invasion of Lebanon - all of which he has denied. ${ }^{58}$ On April 22,

57 Adalah: The Legal Center for Arab Minority Rights in Israel, The Inequality Report, 58.

58 Between July 12 to August 14, 2006, Israel attacked southern Lebanon during which Israel's Air Force flew more than 12,000 combat missions, its Navy fired 2,500 shells, and its Army fired over 100,000 shells resulting in over 1,190 Lebanese and 43 Israeli civilian deaths. See United Nations General Assembly Human Rights Council, Third Session, Implementation of General Assembly Resolution 60/251 of 15 March 2006 Entitled 'Human 
2007, during a visit abroad, Bishara resigned from the Knesset through the Israeli embassy in Cairo and announced his decision to remain abroad due to fears of a "long jail sentence and damage to his public image." 59 In February 2011, the Israeli Knesset made into law what has been dubbed the 'Bishara bill', enabling the parliament to revoke benefits to MKs who do not report to the Israeli police for questioning, a trial, or to serve a prison sentence. ${ }^{60}$ And in March of the same year, the Knesset plenum voted to formally revoke the parliamentary pension received by a former Knesset member.

On June 7, 2010, almost a decade after the first initiatives by the Knesset to strip Arab MKs of their parliamentary immunity, the Knesset House Committee voted to strip the parliamentary privileges of MK Haneen Zoabi, also from the NDA-Balad party. On May 31, 2010, Zoabi participated in the Gaza Freedom Flotilla as passenger on the MV Mavi Marmara, the Turkish-flagged boat carrying humanitarian aid and other supplies to the besieged Gaza Strip. At 2:00 a.m. the ship was commandeered by Israeli Defence Forces (IDF) in international waters, leaving nine activists dead, along with dozens of other activists and ten IDF soldiers injured. A report released by the United Nations Human Rights Council on September 23, 2010 on the incident confirmed that the Israeli military used "live ammunition, soft baton charges (beanbags) and plastic bullets," and explained that the IDF opened fire with live ammunition "from the helicopter ... prior to the descent of the soldiers." The report concluded that "lethal force was employed by the Israeli soldiers in a widespread and arbitrary manner which caused an unnecessarily large number of persons to be killed or seriously injured." ${ }^{\prime 1}$ While Zoabi's parliamentary immunity prevented her

Rights Council': Report of the Commission of Inquiry on Lebanon pursuant to Human Rights Council resolution $S-2 / 1,(\mathrm{~A} / \mathrm{HRC} / 3 / 2)$, November 23, 2006, http://www2.ohchr.org/english/ bodies/hrcouncil/docs/specialsession/A.HRC.3.2.pdf; Jonathan Lis, Yoav Stern and Shahar Ilan, "Balad Chairman Bishara: I cannot receive a fair trial in Israel," Haaretz, April 26, 2007, http://www.haaretz.com/news/balad-chairman-bishara-i-cannot-receive-a-fair-trial-in -israel-1.219014.

59 The Jerusalem Post, "Report: MK Bishara leaves Egypt," April 22, 2007, http://fr.jpost .com/servlet/Satellite?cid=1176152849116\&pagename=JPost/JPArticle/ShowFull.

60 Rebecca Anna Stoil, "Knesset passes law revoking citizenship for treason," The Jerusalem Post, March 28, 2011, http://www.jpost.com/DiplomacyAndPolitics/Article .aspx?id=214202.

61 United Nations General Assembly Human Rights Council, Fifteenth Session, Report of the international fact-finding mission to investigate violations of international law, including international humanitarian and human rights law, resulting from the Israeli attacks on the flotilla of ships carrying humanitarian assistance, (A/HRC/15/21), September 27, 2010, http://www2.ohchr.org/english/bodies/hrcouncil/docs/15session/A.HRC.15.21_en.pdf. 
detention, she was nevertheless extensively interrogated after the raid and, upon release, called for a transparent and independent international investigation into the incident. To penalize Zoabi for her participation in the Gaza-bound ship, the Knesset vote was passed on July 13, 2010 and included revoking her right to have a diplomatic passport, entitlement to financial support should she require legal representation, and her right to visit countries without ties to Israel. Moreover, Zoabi was also denied the right to contribute to Knesset discussions and vote in parliamentary committees. ${ }^{62}$ This vote was the result of numerous confrontational sessions in the Knesset where Zoabi was verbally assaulted by fellow parliamentarians and confronted with a range of racist and sexist statements, attacks and threats. Zoabi has also been targeted by various Knesset members who have called for her to be criminally prosecuted, stripped of her post and, as part of a new legislation mentioned below, even called for the revocation of her Israeli citizenship. ${ }^{63}$ On December 19, 2012, during the course of the 2013 Israeli elections, the Central Elections Committee (CEC) voted narrowly against disqualifying the entire NDA-Balad and the United Arab List parties from participating, but went on to approve by a majority of 19-9 a motion to only bar Zoabi from running for the nineteenth Knesset on the grounds of her participation in the Gaza Freedom Flotilla in 2010. ${ }^{64}$

62 Jonathan Lis, "Arab MK stripped of further parliamentary privileges for role in Gaza flotilla," Haaretz, July 18, 2011, http://www.haaretz.com/news/national/arab-mk-stripped -of-further-parliamentary-privileges-for-role-in-gaza-flotilla-1.373859.

63 Adalah: The Legal Center for Arab Minority Rights in Israel, The Inequality Report, 58. In May 2011, Zoabi was banned from the Haifa University campus from speaking with the Balad party student campus group. Citing the visit as providing "an excuse for exhibiting violent behaviour" the university banned her participation in the student political activity on campus. As an MK, and under The Knesset Members (Immunity, Rights and Duties) Law, Zoabi has the right to enter a university campus without restrictions. Despite the ban, Zoabi attended the scheduled event, accused the university of "using the same tactics as the Shin Bet security service to keep Arab political activity to a minimum" and encouraged students to bring the matter to the attention to university donors. See Jack Khoury, "Haifa University Students protest ban on Israeli Arab MK who sailed on Gaza flotilla," November 15, 2011, http://www.haaretz.com/print-edition/news/haifa-u-students-protest-ban-on -israeli-arab-mk-who-sailed-on-gaza-flotilla-1.324701; Fadi Eyadat, "Arab MK Zuabi visits Haifa University despite campus ban," Haaretz, November 15, 2010, http://www.haaretz .com/news/national/arab-mk-zuabi-visits-haifa-university-despite-campus-ban-1.324825.

${ }^{64}$ In a statement after the CEC decision on Article 7A of The Basic Law: The Knesset (explained above), Adalah, the legal centre representing NDA-Balad, the United Arab List and MK Haneen Zoabi, explains: "Over the past ten years this article has been used repeatedly against Arab candidates and political parties before every round of Knesset elections for calling for 'a state for all its citizens', for example, or for expressing any criticism of Israel's Occupation or support for the Palestinian national struggle for independence. Therefore, the elected representatives of the Arab national minority in Israel find themselves having to justify their struggle for full equality and defend their demands for the 
Most observers in Arab political parties and civil society viewed this vote as an extension of the racist and discriminatory laws targeting Arab citizens which were introduced by the right-wing Netanyahu-Lieberman administration, and various Jewish-Israeli litigators, scholars and newspapers also spoke against disqualification. ${ }^{65}$ By December 30 , the vote of the CEC was unanimously overturned by the Israeli Supreme Court to allow Zoabi to run in the January 2013 elections.

\section{Arab Civil Society: A Non-State Alternative}

Contradictions in the self-designation of the State of Israel as 'Jewish and democratic' render genuine representation of the Arab citizenry an impossible venture. Questions of representation were particularly heightened among the Palestinians in Israel after the 1993 Oslo Accords. The failed results of the Oslo process targeted the Palestinian-Arabs in Israel from two angles. On the one hand, the violent intensification of the broader conflict fuelled a heightened sense of existential threat among Israeli Jews, placing the Arabs in Israel under a marginalizing and repressive security discourse. For a variety of political and ideological reasons, PalestinianArabs in Israel were directly associated with the actions and reactions of Palestinian-Arabs in Jerusalem, the West Bank and Gaza Strip - prompting the state to exert a similar crushing system of control over its Arab citizenry. ${ }^{66}$ At the same time, the historic peace talks that began between Israel and the Palestine Liberation Organization (PLO) in 1993 completely ignored the status of the Arabs in Israel (Rouhana and Ghanem 1998, 330). The Palestinians in Israel were not allies in building Palestinian national

\footnotetext{
right to dignity, in case their positions are deliberately misconstrued as a negation of the state or as support for terrorism." See Hassan Jabareen, "Commentary on the Central Elections Committee Session,"Adalah Newsletter 99 (December 2012), http://adalah.org/ Public/files/English/Newsletter/99-December2012/Commentary-Central-Elections -Committee-Jabareen-December2012.pdf.

65 Responding to the CEC ruling, Attorney Hassan Jabareen remarked that "Israel is the only country in the world in which members of the minority must justify their struggle for full equality" (ibid.). Further, even prior to the Israeli Supreme Court ruling, AttorneyGeneral Yehuda Weinstein voiced his opposition to the CEC ban on MK Zoabi, as well as the barring of any other political parties. Also see Sammy Smooha, "Expert Opinion: Repercussions of disqualifying an Arab political party or one of its candidates in the elections for the 19th Knesset," [December 16, 2012] Adalah Newsletter 99 (December 2012), http://adalah.org/Public/files/English/Newsletter/99-December2012/Expert-Opinion -Smooha-2012-Elections-Disqualifications.pdf and Haaretz, "An unacceptable disqualification," December 21, 2012, http://www.haaretz.com/opinion/an-unacceptable -disqualification-1.486242.

66 For more on this, see Rouhana (1997) and Zureik (1979).
} 
and political agencies, nor were their demands ever considered an important issue on the agenda of the Palestinian national movement (Rouhana and Ghanem 1998, 333). Objections and demands made by the Arab citizenry are always viewed by Israel as an internal Israeli affair, and the PLO has never brought issues of concern for the Arabs in Israel to the fore in political negotiations and discussions. Thus, as Arab needs were almost completely ignored in the domestic Israeli arena, this community was left without representation from all parties. Indeed, an implicit agreement by both the PLO and Israel made this community a forgotten part of the Palestinian people, denying them genuine representation on all sides.

Consequently, Palestinian-Arabs in Israel began the process of building a national democratic movement via a third, non-state alternative: civil society. Formally recognized with the Registry of Associations in the Ministry of the Interior, Palestinian NGOs in Israel are run by Palestinian citizens and aim mainly to serve Palestinian society within the Israeli regime (Payes 2003, 6o). Given the disappointment and disillusionment prompted by the oscillating political situation, the Palestinian-Arab community has employed its civil society to struggle for a re-conceptualization, re-definition and re-arrangement of the issues and contentions included in the dominant political discourse. For instance, seeking to depoliticize certain actions otherwise considered prejudicial to Palestinian interests, the Israeli regime often invokes the need for development. Expropriation of Arab land is commonly presented as a necessary sacrifice for the facilitation of economic development projects that mainly benefit the Jewish population (Payes 2003, 82). In protesting against such measures, Arab NGOs in Israel have often reduced their consequences and, in the process, sparked a debate on topics in Israeli society previously considered non-political. Through such measures, Palestinian civil society has been able to propose alternatives to political relations in Israel, recently culminating in three major declarations, popularly called 'vision documents'.

Published in 2006 and 2007, these so-called vision documents include: The Future Vision of the Palestinian-Arabs in Israel formed under the auspices of the High Follow-Up Committee for the Arabs in Israel; The Democratic Constitution by Adalah; and The Haifa Declaration by Mada al-Carmel: The Arab Center for Applied Social Research (hereafter 'Mada al-Carmel'). These documents were prepared in conjunction with one another, and drafted by a range of Arab political activists, public figures and intellectuals - many of whom participated in the drafting of more than one document thereby allowing for collaboration. They constitute 
the first formal statements by collectives from the Palestinian community in Israel on their placement within Israeli society and politics. Together, these statements touch upon similar themes, and articulate the community's intricate understanding and criticisms of the principles of democracy, representation, citizenship and minority rights in Israel. Further, by deconstructing notions of 'the Jewish and democratic state', illuminating the lack of space for a Palestinian identity in a Zionist state, and pointing to the failures of Israel's project of coexistence, these documents indicate the development of a new consciousness among the Arab community. While they each possess their own distinguishing features and approach the question of Palestinian presence in Israel from a different angle, they are more or less in agreement that Israel must accept responsibility for injustices against the Palestinian people, including recognition of the $N a k b a$, the right of return of Palestinian refugees as per UN Resolution 194, and the Palestinian right to national self-determination within the pre1967 borders.

Of these documents, The Democratic Constitution and The Haifa Declaration deserve particular attention. ${ }^{67}$ Responding to the range of draft constitutions proposed by Israeli groups, none of which posit the right to complete equality among citizens and residents nor recognize the Arab community as indigenous to the land, The Democratic Constitution (hereafter 'DC') aims to provide the Israeli Knesset with an alternative vision. The DC is essentially a draft constitution whose conception of liberties and rights is based upon the legal experiences of established democratic states along with a broad range of international human rights covenants and declarations. ${ }^{68}$ This document addresses a range of logistical legal questions of governmental and judicial powers, citizen and minority participation in political decision-making and operative issues pertaining to the right to sustainable development, due process, privacy, health and housing, and freedoms including, among others, political expression and association, mobility, and conscience. Throughout its address, the DC makes references to international legal covenants to which Israel is already party. Perhaps its most important contribution is the provision of an account of citizenship based upon the principle and right of non-discrimination. Stressing the historical significance of the

67 See Appendices I and II for selections of both documents.

68 Adalah: The Legal Center for Arab Minority Rights in Israel, The Democratic Constitution, March 2007: 5, http://www.adalah.org/Public/files/democratic_constitution -english.pdf. 
synthesis between territory and citizenship for issues of civil rights, the first clause in this document states that " $\mathrm{t}$ ] he borders of the State of Israel are the borders of the territory which was subject to the Israeli law until 5 June 1967." ${ }^{\circ 9}$ The authors of the DC explain:

The test of belonging to 'a clear territory' facilitated the definition of 'Who the citizen is' that stands as an equal before the state without intermediary agents. This is particularly true with regard to the State of Israel, where the lack of a defined border contributed to the fact that tribal and ethnic affiliation became the essence of citizenship. This also explains why Israeli law deals with 'Who a Jew is' and not 'Who a citizen is'; and it is no coincidence that the citizenship of Jews living outside the Green Line, for example, is stronger than that of the Arab citizens who live within the Green Line. .... Indeed, the public perception that the citizenship of some of the citizenry is temporary due to a lack of defined borders will continually harm the everyday status of these citizens, thereby affirming the truth of the statement: Empires have frontiers, but democracies have borders. ${ }^{70}$

With this clause, the DC challenges the fusing of Jewish identity and Israeli citizenship. In doing so, it also sets the ground for the abrogation of the current dynamic where the Jewish people are the sovereign power in Israel, regardless of their actual citizenship. ${ }^{71}$

In conjunction with many of the claims made in the DC, The Haifa Declaration (hereafter 'HD') aims to clearly articulate the collective vision of the Palestinian community within Israel, "in their effort to assert their national identity, national rights, and their right to democracy and equal citizenship." ${ }^{2}$ Published on Nakba Day, May 15, 2007, and steeped in the discourse of democratic citizenship, equal representation and historical justice, the HD also aspires to generate dialogue both within the Arab community and with the Jewish-Israeli society. The document begins by positing a reading of the Palestinian experience in Israel and its multileveled relationship with the rest of the Palestinian people, the Arab states, and the Israeli regime, and goes on to elaborate on the effect of these attachments on the national identity of the community.

69 Ibid., 6.

70 Ibid.

71 That said, the aims of the DC are relatively humble. Its drafters hold that if it manages to capture the enormous difference between the DC and proposals put forward by other Israeli groups, and to fuel an objective public engagement on the question of rights and freedoms in Israel, "then we will have taken an important step forward in the issues of racial equality, freedoms and social justice" (ibid., 3 ).

72 Mada al-Carmel: Arab Center for Applied Social Research, The Haifa Declaration, May 2007: 5, http://www.mada-research.org/en/files/2007/og/haifaenglish.pdf. 
Described as sustained by their "uninterrupted relationship" to the land and "continued connection" to the Palestinian people, the national identity of the Arabs in Israel is explained as having withstood efforts by the Zionist project to truncate their identity into an "Israeli Arab" affiliation. ${ }^{73}$ From this, the HD outlines racially discriminatory land, economic, immigration, and citizenship laws, among others, enacted by the State of Israel, arguing that the principle of equality is a key constituent of Israeli citizenship, without which genuine Arab affiliation with the state is impossible. Significantly the HD also addresses the Jewish narrative. Of all of the published 'vision documents', the HD is the only statement which seriously acknowledges the Jewish narrative of persecution. Having outlined the Palestinian narrative of the Nakba and the process of the Zionist settlercolonial project in Mandate Palestine, the HD states:

We are aware of the tragic history of the Jews in Europe, which reached its peak in one of the most horrific human crimes in the Holocaust perpetrated by the Nazis against the Jews, and we are fully cognizant of the tragedies that the survivors have lived through. We sympathize with the victims of the Holocaust, those who perished and those who survived. We believe that exploiting this tragedy and its consequences in order to legitimize the right of the Jews to establish a state at the expense of the Palestinian people serves to belittle universal, human, and moral lessons to be learned from this catastrophic event, which concerns the whole of humanity. ${ }^{74}$

Despite heated discussions among its drafters as to whether to include the Jewish narrative in a document meant to communicate the Palestinian social and historical experience, the HD is able to accept the Jewish narrative, but outside of a Zionist framework. In doing so, the HD illustrates that the two narratives are not antithetical to one another, providing an important preliminary framework for mutual recognition and genuine coexistence.

\section{Response to the Rise of Arab Civil Society: The Case of Ameer Makhoul}

The political initiatives of the Arab citizenry are shaped by the particular dynamics of their citizenship. The patterns or degrees of inclusion (whether full, partial, differential or exclusionary) are central to understanding how individuals and social collectives respond to the practices of the regime. In other words, patterns of inclusion and exclusion are

\footnotetext{
73 Ibid., 8.

74 Ibid., 15.
} 
important for understanding the social actions and identity that is mobilized by the citizen community. The recent case of Ameer Makhoul, the former director of Ittijah: The Union of Arab Community-Based Associations, illuminates this question. Ittijah is an umbrella organization, or coalition, that serves as a medium of communication between various Palestinian civil society groups in Israel, encouraging them to meet regularly and network to develop communal and political ties. Central to Ittijah's mandate is advocacy around the socio-cultural, political and economic needs of Palestinian-Arabs at the local Palestinian, regional Arab and international levels. ${ }^{75}$ As the director, and in addition to facilitating cooperation among Palestinian NGOs, a lot of Makhoul's work was primarily centred around monitoring the restrictions on the social and political freedoms of the Arab citizenry, including its political representatives, denouncing these restrictions and openly voicing sharp criticism both in Israel and abroad.

On April 22, 2010, Makhoul, an Israeli citizen, arrives at the Sheikh Hussein Bridge terminal at the Jordan River, intending to exit Israel. During the passport control, he is informed that the Interior Ministry issued an order on April 21 prohibiting him from exiting the country for a period of two months. The order banning Makhoul from traveling abroad is based on Regulation 6 of the Emergency Regulations - Foreign Travel Law (1948) and was issued without "any prior suitable, transparent and fair hearing. ${ }^{76}$ As a result, this order violates even Israeli laws around the freedom of movement and due process. At 3:10 am on May 6, around sixteen members of the GSS and the Israeli police entered the Makhoul family home and arrested Ameer Makhoul. On the same night, the security services also raided the Ittijah office in Haifa. The GSS confiscated personal items belonging to Makhoul, his wife and two daughters, including office equipment, documents, computer databases, maps, the family's mobile phones, laptops, a camera and a tape recorder, among other things. ${ }^{77}$ Despite the ambiguity of the security reasons cited for Makhoul's arrest,

75 In August 2004, Ittijah was granted Special Consultative status from the United Nations Economic and Social Council making it the first Palestinian civil society organization in Israel to achieve consultative status with a United Nations body.

76 Adalah: The Legal Center for Arab Minority Rights in Israel, "Following Adalah's motion on behalf of Arab journalists, the I'lam Center and Human Rights Organizations, Magistrates' Court lifts gag order on detention of Arab political activists Ameer Makhoul and Dr. Omar Saeed," Press Release, May 10, 2010, http://www.adalah.org/eng/press releases/pr.php?file=10_05_10.

77 Ibid. 
the Israeli security services acquired the approval of the Petakh Tikva Magistrates' Court to prevent Makhoul from meeting a lawyer. In addition, a gag order was issued on Makhoul's case prohibiting coverage relating to the arrest by the Israeli media.

For twelve days, Makhoul was held in incommunicado detention and was prevented from meeting a lawyer as the court continuously rejected appeals made by his legal defence team against the prohibition on meeting a lawyer. ${ }^{78}$ During this time and as a result of his classification as a "security detainee," hearings would be held in Makhoul's absence and though he was brought to the courtroom he was prohibited from appearing at his own hearings. ${ }^{79}$ Adalah reports that, throughout these hearings, "secret information" was traded between the court and the GSS along with questions asked and notes passed between the two. ${ }^{80}$ Further, all information pertaining the investigation and to Makhoul's medical and physical condition while in detention was declared classified. In effect, the view of the defence was virtually absent in the courtroom.

As to the category of "security prisoners," it is important to note that regardless of the nature of the violation, Israeli prison authorities generally consider Arab political detainees as security prisoners. This was stressed by attorney Abeer Baker who explained that this classification determines a person's treatment by the Israeli Prison Services including the prison to which she/he is assigned, the prison wing where she/he will serve the sentence, the provision of a leave, guarded home visits, and access to telephone calls from prison. ${ }^{81}$ The distinction between 'criminal' and 'security' prisoners was sanctioned by the Israeli Supreme Court, and while it is claimed that it is applied to both Arab and Jewish prisoners, Baker argues that in practice it is only Palestinian prisoners who suffer the devastating ramifications of being declared a security prisoner.

78 Makhoul's legal team was comprised of Attorney Hussein Abu Hussein and Adalah Attorneys Orna Kohn and Hassan Jabareen. Attorney Avigdor Feldman was later added.

79 Adalah: The Legal Center for Arab Minority Rights in Israel, "Court rejected Appeal against prohibition on meeting with lawyers for Ameer Makhoul and extended the detention of Makhoul and Dr. Omar Saeed," Press Release, May 12, 2010, http://www.adalah.org/ eng/pressreleases/pr.php?file=12_05_10.

80 Adalah: The Legal Center for Arab Minority Rights in Israel, "Ameer Makhoul's legal defence team declares they would not participate in detention hearing tomorrow, 17 May, if he is prohibited from meeting his lawyers," Press Release, May 16, 2010, http://www .adalah.org/eng/pressreleases/pr.php?file=16_05_10_1.

81 Abeer Baker, "The definition of Palestinian prisoners in Israeli prisons as 'Security Prisoners' - Security semantics for camouflaging political practice," Adalah's Review, 5 (Spring 2009): 65-78. www.adalah.org/upfiles/2012/AR_5_ENG_MAS_NEW\%2ofinal.pdf. 
Jews imprisoned or detained due to attacks on Arabs for ideological reasons continue to benefit from the rights provided to criminal prisoners, even if they are officially classified as security prisoners. Consequently, prisoners who are Palestinian citizens of Israel continue to find themselves on a double periphery. On the one hand, Palestinian political prisoners who are Israeli citizens are discriminated against as compared to Jewish prisoners in the harsher sentences they receive and in the difficult prison conditions they are subjected to. ${ }^{82}$ At the same time, Palestinian citizens who are incarcerated are excluded from Israeli-Palestinian prisoner-release agreements and from candidacy for early release as their situation is considered an internal Israeli issue - a product of the Oslo Accords. ${ }^{83}$

On May 16, and given the conditions imposed on him as a security detainee, Makhoul's legal defence team announced that they would not participate in the detention hearing in the Petakh Tikva Court if he was not permitted to meet his lawyers. Adalah stated:

The legal defence team is convinced that under these circumstances, due to the total lack of respect for due process, the representation of Ameer Makhoul in the detention hearings has become meaningless. In this instance, the legal system is simply a rubber stamp for the Shabak. ${ }^{84}$

This was the first time in Israel's history that a defence team had threatened to boycott the legal proceedings after being denied access to their

82 Further, in March 2011, the Knesset approved a law to enable the Israeli Supreme Court to revoke the citizenship of anyone convicted of the security charges of espionage, treason or aiding the enemy during war. According to this law, only individuals with dual citizenship can have their Israeli citizenship entirely revoked. Those without dual citizenship could still have their Israeli citizenship stripped, but would be given status equivalent to what Israel grants foreign workers. See Jonathan Lis, "Knesset passes law to strip terrorists of Israeli citizenship," Haaretz, March 28, 2011, http://www.haaretz.com/news/national/ knesset-passes-law-to-strip-terrorists-of-israeli-citizenship-1.352412.

83 Moreover, a recent bill proposed by the Knesset's Interior Committee to amend the Prisons Ordinance to increase the severe restrictions on meetings between security prisoners and detainees and their legal representatives. The bill expands the grounds on which a prisoner may be restricted from meeting an attorney and increases the current periods in which a ban on such meetings may be imposed. Under the bill, the Israel Prison Services authority can prevent a prisoner from meeting with his or her lawyers is extended for up to 96 hours, and the courts can extend a ban for a total period of one year, as opposed to the three months under the existing law. See Adalah: The Legal Center for Arab Minority Rights in Israel, "Proposed bill allowing for one-year ban on meetings between prisoners and their attorneys is unconstitutional," Press Release, June 28, 2010, http://www.adalah.org/eng/ pressreleases/pr.php?file=28_06_11.

84 Adalah: The Legal Center for Arab Minority Rights in Israel, "Ameer Makhoul's legal defence team." 
client. ${ }^{85}$ In response, on May 18 , the order prohibiting his meeting with a lawyer was lifted by the Petakh Tikva Magistrates' Court and Makhoul was able to consult with his defence team. ${ }^{86}$ At this point, the defence realized that during the time they were prohibited from meeting Makhoul, his interrogators had employed "prohibited methods of interrogation in violation of the absolute prohibition on torture under international law and Israeli Supreme Court decisions." ${ }^{\prime 87}$ The refusal of the GSS to release his medical records supported this realization.

Three weeks after beginning his detention, on May 27, Makhoul was charged with "assistance to the enemy in a time of war, conspiracy to assist an enemy [and here they mainly mean Hezbollah], aggravated espionage, and contact with a foreign agent." ${ }^{88}$ When he finally appeared in open court, Makhoul categorically denied the relevance of all charges against him. On June 14, state prosecutors announced they have 'secret evidence' against Makhoul, and that this evidence could not be revealed to his legal defence team due to security reasons. ${ }^{89}$ Moreover, the prosecutors

85 Adalah points out that it was not only meetings with lawyers which were denied to Makhoul: "In addition to being barred from meeting with his lawyers, he is also unable to meet his family (his wife Janan and their two daughters), and has no right to make a telephone call or send a letter. In addition there is no video or audio recording or full written record of the investigations to which he has been subjected over the last eleven days. These conditions, his almost complete isolation for the outside world and the violation of his right to due process are all conducive to torture and/or cruel, inhuman and degrading treatment" (ibid.).

86 On July 1, 2010 Makhoul's defence team announced that their discussions with Makhoul were being wiretapped. Correspondence between the defence team and Makhoul at the Gilboa Prison and Kishon detention center was permitted only either via telephone, separated by a glass screen, or with prison guards standing next to the lawyers with Makhoul, listening to the conversation. Makhoul's lawyers were denied a separate room usually provided for meetings between lawyers and detainees, on the basis that these facilities were only for the use of 'criminal' detainees, and not 'security' detainees. Not aware that their discussions with him over the telephone were being recorded, Makhoul's lawyers only discovered the recording from a notice in one of the rooms, stating that all conversations were recorded. See Adalah: The Legal Center for Arab Minority Rights in Israel, "Illegal wiretap on Ameer Makhoul's discussions with his legal defence team, lawyers demand prompt criminal investigation," Press Release, July 1, 2010, http://www.adalah.org/ eng/pressreleases/pr.php?file=01_07_10.

87 Adalah: The Legal Center for Arab Minority Rights in Israel, "Serious suspicion of Shabak (GSS) use of illegal methods of interrogation against human rights defender Ameer Makhoul," Press Release, May 18, 2010, http://www.adalah.org/eng/pressreleases/pr.php ?file=18_05_10_1.

88 Adalah: The Legal Center for Arab Minority Rights in Israel, "Ameer Makhoul and Omar Saeed vehemently deny charges against them," Press Release, May 27, 2010, http:// www.adalah.org/eng/pressreleases/pr.php?file=27_05_10.

89 Adalah: The Legal Center for Arab Minority Rights in Israel, "District Court sets next hearing in Ameer Makhoul's case on 27 June 2010; State prosecutor announces 'secret 
announced evidence in the form of a videotaped admission to the said charges. Responding to the announcement of a taped confession, the defence team pointed out that admission to acts he "did not commit" was made under duress from the extensive "illegal methods employed" against Makhoul during the initial days of his arrest. ${ }^{90}$ In the end, and despite all of the travesties associated with this case, on January 30, 2011, Ameer Makhoul was sentenced to nine years in prison with one of these years as a suspended sentence.

\section{Operative and Budgetary Level}

Palestinian citizens of Israel are denied proportional representation and access in the realms of budgets, resources and land allocations. As equality among citizens is not legally entrenched, the Israeli legal system is able to emphasize the Jewish and Zionist character of the state. Major Jewish and Zionist organizations are granted special status as quasi-governmental bodies. These organizations manage land, housing and service provision, almost exclusively serving the Jewish population. For instance, The World Zionist Organization - Jewish Agency in Israel (Status) Law (1952) authorizes the two organizations to function as quasi-governmental institutions in order to advance the goals of the Zionist Movement, including the maintenance and support of cultural, housing, educational, scientific, religious, and social and health service institutions. The internal regulations of these organizations explicitly seek to benefit Jews only, and as no non-Jewish organizations are granted similar status, this produces a remarkably lower quality of life for Palestinian-Arabs. ${ }^{91}$

evidence' that will not be disclosed to legal defence team," Press Release, June 14, 2010, http://www.adalah.org/eng/pressreleases/pr.php?file=14_06_10.

90 On this, Adalah writes that the duress included "protracted sleep deprivation and continuous interrogation, while being shackled tightly to an under-sized chair that was bolted to the floor to prevent it from moving. His hands were cuffed to the back of the chair in a way that stretched his arms and shoulders sharply backward. His legs were folded backwards flanking the chair, with his knees turned toward the floor. When, after hours of being bound in this stress position while under intense interrogation, Makhoul complained of being in excruciating pain, the GSS interrogators proceeded to cuff his legs to the chair. They also threatened that he would be permanently crippled from the interrogation." See Adalah: The Legal Center for Arab Minority Rights in Israel, "Ameer Makhoul and Omar Saeed vehemently deny charges against them."

91 In fact, the Constitution of the Jewish Agency states that "land is to be acquired as Jewish property and ... the title of the lands acquired is to be taken in the name of the JNF to the end that the same shall be held the inalienable property of the Jewish people. The Agency shall promote agricultural colonization based on Jewish labour, and in all works or undertakings carried out or furthered by the Agency, it shall be deemed to be a matter of 
American academic Ian Lustick outlines how, after 1948, the Zionist agencies that worked to colonize Palestine in the pre-state period were bestowed a central role and statutory status after the establishment of the new state. With the emergence of Israel as a sovereign state, a kind of 'division of labour' was arranged: the Jewish Agency remained the principal organization responsible for encouraging Jewish immigration and integrating new immigrants into Israeli society; the JNF continued to obtain land and lease it to Jewish settlements in cooperation with institutions of the Israeli government, including the ILA and the Ministry of Agriculture; as the the second largest employer after the Israeli government and the official representative of all Israeli workers in the country, the Histadrut, a Jewish trade union, continued its attempts to improve the circumstances of the Jewish working class; and the Haganah, a Jewish paramilitary organization formed and sustained by the Histadrut, became the foundation of the IDF which today is the armed forces and the largest and principal institution in the Israeli government (Lustick $1980,95) \cdot{ }^{92}$

The broad ideological objective of maintaining Israel's Jewish character continues to manifest in these institutions that actively advocate Jewish domination in Mandate Palestine, mass Jewish immigration, growth of Jewish land ownership, and other Zionist goals (Lustick 1980, 89). It is important to appreciate the devastating effect of the autonomous existence of these national Zionist institutions on the Arab population. Palestinian NGOs do not have access to the organizational, financial and administrative resources of these public and national institutions. Thus they have limited abilities to impose significant changes on the racially hierarchical Israeli system. Moreover, despite being quasi-governmental organizations, the constituency of these Zionist agencies is not the entirety of Israel's citizenry, but rather a transnational collective: the Jewish people. As a result, the officially recognized organizations, institutions, state holidays, symbols, and figures are exclusively Zionist and Jewish (Ghanem 1998, 432). In addition, as mentioned above, while Arabic is also an officially recognized language, the Hebrew language is dominant in all official

principle that Jewish labour shall be employed." That the World Zionist Organization and Jewish Agency are key participants in the Admissions Committees mentioned above also illustrates the level to which Palestinian citizens and residents will be denied access to the land (see Halabi 2004, 3-4).

92 Lustick's contribution to the study of Arabs in Israel is more closely examined in Chapter Five where it is placed alongside other scholarly contributions on this subject, and again in Chapter Six. 
spheres of Israeli society. ${ }^{93}$ This severely discriminates against PalestinianArabs as it impedes their ability to participate in political, social and cultural activities on an equal basis with Israeli Jews.

Budgetary discrimination against the Arab community fuels the unequal distribution of resources to Arab and Jewish localities, thus furthering the limited economic development of the Arabs in Israel (Ghanem 1998, 429, 435). In the education sector, Palestinian-Arabs are denied participation in setting educational directions, subjected to discriminatory allocation of state funding and educational resources, and are severely underrepresented in policy-making positions in the Israeli Ministry of Education. Systematic, structural, and institutionalized discrimination hampers the ability of Palestinian students in Israeli state-run schools to participate and contribute politically, socially, culturally, and economically. An analysis of illiteracy rates in Israel according to ethnicity and gender indicates that the Palestinian-Arab population has higher percentage of illiteracy than the national average on both counts. ${ }^{94}$ In fact, in 2008 , around 13.4 percent of Arab women were considered illiterate, relative to 3.4 percent of Jewish women, and 5.5 percent of Arab men were illiterate compared to only 1.9 percent of Jewish men. ${ }^{95}$

Further, the Israeli education system is based on The State Education Law (1953). Amended in February 2000, this law sets educational objectives for state schools that emphasize Jewish history and culture. Stated in Article 2 of the law, the education system seeks primarily to advance the understanding of Zionist ideology and preserve the Jewish nature of the state by teaching its history, culture and language. ${ }^{96}$ This deficient educational focus is also framed by a deficient educational structure. While Arab schools have a separate curriculum, it is designed and overseen by the Israeli Minister of Education. Within this ministry, Arabs account for only 6.2 percent of the total number of employees and, consequently, there are

93 In fact, the previous eighteenth Knesset, was looking at a draft bill which proposes the removal of Arabic as an official language in Israel. This initiative requires a rescission of a British-Mandate era law in Palestine from 1922 that which adopted Arabic, Hebrew and English as official languages.

94 For a thorough account and up-to-date statistics on the state of Arab education in Israel, see Katie Hesketh and Sawsan Zaher, "New Data on Educational Access/Attainment of Arab Students in Israel," Adalah's Newsletter 63 (August 2009), http://www.adalah.org/ features/education/New_Data_on_Education_August_2009.pdf.

95 Ibid.

96 Khaled Abu-Asbeh, "Arab Education in Israel: Between the Discourse of Struggling Identity and Low Achievement," Adalah's Newsletter 63 (August 2009), http://www.adalah .org/features/education/Arab_Education_in_Israel_English_for_Khaled_FINAL.pdf. 
almost no Arab instructors or administrators with decision and policymaking powers in the Israeli education system. As a result, Arab state-run schools are faced with a discriminatory curriculum which allots more time to learning the Torah along with other Jewish and Zionist texts than to studying the Qur'an, the New Testament or literature produced by Arab scholars. ${ }^{97}$ Conversely, Jewish state-funded religious schools maintain autonomous control over the design and implementation of their curriculum. In addition, in July 2009, the Ministry of Education launched a program seeking to entrench Zionist thought in the minds of Arab youth in Israel. It distributed 'national anthem kits' to schools throughout the country in an attempt to arouse Arab commitment to and empathy for the Israeli national anthem, and its associated values of a Jewish-Zionist state. ${ }^{98}$ Moreover, in August of the same year, the Education Minister imposed a ban on the teaching of the Nakba, the result of which was a stern rejection and widespread condemnation of this discriminatory ban by the Follow-Up Committee on Higher Education, a public committee established in 1984 to represent the Arab public in Israel with regard to Arab education.

Regarding budgetary allocation for religious cultivation, after the 1967 war and the Israeli military occupation of East Jerusalem, the West Bank and Gaza Strip, the Israeli government implemented The Protection of Holy Sites Law (1967). This law aimed to safeguard and preserve sacred spaces from desecration, and from anything that could obstruct access to these places by followers of religious traditions or could offend their religious sensitivities. ${ }^{99}$ The Minister of Religious Affairs is responsible for the

97 Ibid. University matriculation exams include questions on Judaism, but not on the Muslim, Christian, or Druze faiths, and in addition to such direct discrimination in the classrooms, numerous studies have found that Israeli textbooks contain persistent negative and racialized references to Arabs and Palestinians. For an excellent account of the representation of the Palestinian people in the Israeli education system, see Peled-Elhanan (2012). Further, a source at the Israeli Ministry of Education recently noted an escalation in racism among Israeli students. Citing the racist political discourse as fuelling anti-Arab racism among Jewish-Israeli students in schools, the source states "We're not talking about a minority, or children from families that have extreme political views, but about normal children who are afflicted with ignorance .... The political discourse in recent years has given them the legitimacy to be prejudiced." In response to the rise of anti-Arab racism in Israeli schools, a group of teachers signed a petition calling on Education Minister Gideon Sa'ar to take action. See Tomer Velmer, "Student's answer on civics test: Death to Arabs," Ynet News, January 19, 2011, http://www.ynetnews.com/articles/o,7340,L-4015645,0o.html.

98 Jonathan Cook, "Palestinians in Israel forced to study Zionist anthem," The Electronic Intifada, July 28, 2009, http://electronicintifada.net/content/palestinians-israel-forced -study-zionist-anthem $/ 8364$.

99 Report by European Center for Law and Justice and American Center for Law and Justice, Religious Freedom and Religious Persecution Issues in Israel and the Palestinian Territories, January, 2008, http://www.eclj.org/PDF/080123_ISRAEL_MEMO.pdf. 
implementation of this law, and is required to regulate holy sites in general and not selectively on the basis of their religious affiliation. However, while The Protection of Holy Sites Law (1967) applies to holy sites of all religious groups within Israeli controlled lands, including Jerusalem, the Israeli government only implements regulations for Jewish sites. ${ }^{100}$ Non-Jewish holy sites are not identified, safeguarded or preserved to the same extent under this law because the government does not recognize them as official holy sites. Indeed, in early 2007, there were 135 officially recognized holy sites all of them Jewish. Though prominent and familiar sites do receive protection due to their international importance, many Christian and Muslim sites are neglected, inaccessible or at risk of exploitation by real estate entrepreneurs, corporations, and local authorities. For instance, in the 2009 International Religious Freedom Report, the United States Department of State writes that "Christian pilgrimage sites around the Sea of Galilee face periodic threats of encroachment from district planners who want to use parts of their properties for recreation."101 The Report also states that the State of Israel will even sometimes allow private individuals or local authorities to transform old mosques into galleries, recreation centres, restaurants and museums, and often restricts entry into non-Jewish holy sites. Moreover, it notes that, in the past, only diplomatic initiatives have prevented Israeli government initiatives of this kind. Taken together, the lack of recognition of Christian and Muslim places of worship results in discrimination in the designation of the state budgets for holy sites and unjustifiably disregards the religious and historical significance of the sites. Restrictions placed on access to non-Jewish holy sites, along with limits to funding, protection, and service provision for those sites, significantly contribute to religious tensions in Israeli controlled lands. ${ }^{102}$ In Israel proper, many Palestinian localities do not have Christian or Muslim places of worship available given the inability of the municipalities to build or legally maintain a church or mosque. For instance, while there is one synagogue for every 700 Jews living in Beer el-Sabi' (Be'er Sheva), there does not exist a single functioning mosque for the city's 5,000 Muslims. ${ }^{103}$

100 Adalah: The Legal Center for Arab Minority Rights in Israel, "Additional Information to the UNCERD."

101 United States Department of State, Israel and the Occupied Territories: International Religious Freedom Report 2009, Annual Report, October 26, 2009, http://www.state.gov/j/ $\mathrm{drl} / \mathrm{rls} / \mathrm{irf} / \mathbf{2 0 0 9 / 1 2 7 3 4 9 . h t m . ~}$

102 Adalah: The Legal Center for Arab Minority Rights in Israel, "Legal Advocacy, Supreme Court Petitions: Religious Rights," http://www.old-adalah.org/eng/legaladvocacy religious.php.

103 The only existing place of worship for Muslims in the city, the Big Mosque, was used as a moqsue from 1906-1948, yet after the establishment of the State of Israel it was used as 
Multi-level discrimination against Palestinians through laws, access to rights and resources, and government policies has particularly devastating consequences for the lives of Palestinian women. ${ }^{104}$ Overall, and faced with patriarchal rules and customs reflecting a gender hierarchy in their societies, Palestinian women citizens of Israel face discrimination on three distinct yet connected levels: as members of an underdeveloped minority population, as women living in Israel, and as women in Palestinian society. These simultaneous and interrelated dynamics severely compromise the social and economic welfare of Palestinian women. This is principally the case in the area of health care. Generally speaking, women in Israel are a vulnerable group in matters of health, but obtaining access to adequate health care is particularly difficult for many Palestinian women. Surveys repeatedly show that Arab women score worse than all other social groups in many health indicators, including, among others, life expectancy, incidence of chronic illness, obesity and breast cancer (Khatib 2012, 31). There are no major public hospitals in the Arab sector and in many Palestinian villages and towns no gynaecological services are available. Women must therefore travel long distances to major cities to receive women's health services; a lack of safe roads and societal taboos against traveling alone make these long distances prohibitive for many. Having reached a hospital, women are faced with unaffordable costs and language barriers. In areas of Israel where the economic and social situation is particularly trying for Palestinian citizens, such as the Naqab and the 'unrecognized' villages, women often bear the brunt of the difficulties. Overall, government budget and resource provisions are consistently greater for Jewish citizens and communities than they are for Palestinian-Arabs. Discriminatory standards and criteria are applied by governmental and state-sponsored institutions and effectively exclude Arabs and disadvantage this population as a whole - with particularly devastating effects on marginalized segments within the community.

a court and prison, and later as a museum. Since 1991, the Big Mosque has stood empty and neglected and when the city's Muslims sought to use it as a mosque, the municipality sought instead to transform the structure into a museum or an Islamic Cultural Center (ibid.).

104 While I am not examining the particular situation of Palestinian women in Israel in this book, an account of the multifaceted discrimination faced by women in Israel is a source of immense insight for understanding the Israeli incorporation regime. For strong feminist analysis of gendered citizenship in Israel see Shalhoub-Kevorkian (2004, 2007, 2009). See also Kanaaneh (2002); Kanaaneh and Nusair (2010); and Herzog (2004). Another analysis read through an anti-colonialist and feminist lens and informed by a Marxist critique, is Abdo (2011), a contribution that is examined in Chapter Five below. 
Further, racial and gendered discrepancy also exists in the area of employment. According to the Industry, Trade and Labour Ministry and the Israeli Central Bureau of Statistics, in 2008 Arab men earned less than their Jewish counterparts for the same work and, by the same token, Arab women had significantly lower employment rates. ${ }^{105}$ In fact, while 66.6 percent of Jewish women were employed that year only 22 percent of Arab women were employed, whereas the employment figures for Arab and Jewish men were almost the same, at 67 percent and 68.8 percent respectively. Moreover, the data shows that in 2008, the average gross salary per household was also much lower for Arab citizens, standing at 8,818 NIS compared to 14,242 NIS for Jewish-Israeli households. All in all, the data indicated that the more education Arab workers have, the greater the gap is between their average monthly income and that of their Jewish counterparts.

Key to the operational level of discrimination is the configuration of land. ${ }^{106}$ When it comes to land allocation, Arabs face widespread discrimination in national and regional zoning plans - the wide extent of which cannot be covered here. Suffice to say, there exists in Israel a multi-faceted framework of laws and military regulations, which have granted the state the legal authority to confiscate Palestinian land and property. ${ }^{107}$ First codified by the British Mandatory government, and later adopted by Israel, The Land Ordinance Law (1943) sanctioned the confiscation of private lands for "public purposes," which was most often defined by Israel as serving the needs of the Jewish population. Further, Israel also adopted the Emergency Regulations left behind by the British Mandate.

105 Haim Bior, "Israeli Arabs earn less than Jews despite working longer hours, data shows," Haaretz, February 19, 2011, http://www.haaretz.com/themarker/israeli-arabs-earn -less-than-jews-despite-working-longer-hours-data-shows-1.337866.

106 Two political notions are essential to any understanding that claims to reflect the historical and current realities of the Zionist-Palestinian conflict. The first is the acknowledgment that the struggle for Palestine has always been a struggle over land, both as a space for the fruition of culture, and as a resource for communal development. Even the most liberal Zionist thinkers in the early twentieth century asserted that the colonization of Palestine has to go in two different directions: Jewish settlement in Eretz Israel and the resettlement of the Arabs in this to neighbouring Arab states. The second notion crucial to the understanding of this conflict is the realization that this struggle over territory continues today, and is not limited to Jerusalem, the West Bank and Gaza Strip. Rather, areas with a significant Arab population within the pre-1967 borders of Israel (most significantly the Galilee and the Naqab) continue to serve as sites for what Israeli geographers and urban planners have named spatial "policies of Judaization" - which historical revisionists are now correctly starting to label ethnic cleansing (see Pappé 2006; Yiftachel 1999).

107 See COHRE and Badil, Ruling Palestine, for a more detailed account of legal land confiscation measures by the State of Israel since its inception. 
These regulations allowed military commanders to forcibly declare areas "closed" and to deny access of residents to their homes. Interestingly, these laws were first introduced in 1936 by the British as emergency policies to quell the Arab Revolt between 1936-1939 against Anglo-Zionist colonialism, sentencing many Arab insurgents to death in the process. They were only later modified to their present form as the British Mandatory Defence (Emergency) Regulations in 1945, and mainly done so they could be employed against Zionist military organizations, including Lehi (Lohamei Herut Israel, "Fighters for the Freedom of Israel") and Irgun (Irgun Zvai Leumi, the "National Military Organization") (Jiryis 1976, 9-11). Palestinian lawyer and Israeli citizen, Sabri Jiryis, outlines Jewish voices of opposition to these laws before the establishment of the State of Israel at a Lawyers Association Conference in Tel Aviv in 1946. Dr. Moshe Dunkelblum, a future Israeli Supreme Court Judge, held that "as lawyers, we are especially concerned because they violate the basic principles of law, justice and jurisprudence" (Jiryis 1976, 11). Dr. Bernard Joseph of the Jewish Agency depicted these laws as having "deprived [the country] of the elementary protection which the laws of any civilized country afford its inhabitants." 108 And future legal advisor to the new Israeli government, Yaacov Shimshon Shapira, held that "[e]ven in Nazi Germany there were no such laws" and that "[o]nly in an occupied country do you find a system resembling ours" (Jiryis 1976, 12). Jiryis explains:

With the establishment of the State of Israel, one might have expected one if its first steps to have been the repeal of these oppressive imperialist laws. Not only did they remain in effect (with the exception of one part relating to illegal immigration to Palestine), but the new regime employed them as extensively as the old - as if nothing had happened (Jiryis 1976, 13).

Indeed, many Palestinian-Arab citizens of Israel today find that they are still denied access to their homes because they sit on land in a "closed area." Additionally, in 1950, the newly established state passed The Absentee Property Law, defining all those who were expelled, fled, or left the country between 1948 and $195^{2}$ as "absentees" and their property as "absentee property." The first of a masterly sequence of laws aimed at the expropriation of Arab land, The Absentee Property Law (1950) re-defined the legal status of the property and lands of Palestinians outside of Israel.

108 Jiryis continues that “... the regulations expressly reintroduce provisions such as were known in Europe before the era of liberty and, in recent times, in totalitarian states" (ibid., 11-12). 
The property and lands of refugees and internally displaced persons were confiscated, transferred to an ad hoc "Custodian" of Absentee Property, and eventually used for the purposes of Jewish settlement. Without being openly racially discriminatory, provisions in this law ensured that the 'absent' persons were understood not to include Jews. For instance, this law was also applied to the Palestinians who involuntarily became citizens of the State of Israel and, at the time, about half of the population (an estimated 40,000 to 75,000 people) were not at their usual place of residence as defined by the law. These individuals who remained inside Israel but were not at their place of residence were defined as "present absentees" and prevented from reclaiming their lands. As outlined by American professor Don Peretz, in Israel and the Palestine Arabs (1958):

Every Arab in Palestine who ... left his town or village after November 29, 1947, was liable to be classified as an absentee under the regulations. All Arabs who held property in the New City of Acre, regardless of the fact that they may never have traveled farther than a few meters to the Old City, were classified as absentees. The thirty thousand ${ }^{109}$ Arabs who fled from one place to another within Israel, but who never left the country, were also liable to have their property declared absentee. Any individual who may have gone to Beirut or Bethlehem for a one-day visit, during the latter days of the [British] Mandate, was automatically an absentee (Peretz 1958, 152; also quoted in Jiryis 1976, 84).

Assessments of the total amount of lands Israel defines as "abandoned" and claims ownership over range between 4.2 and 5.8 million dunums, and in the first years of its establishment (between 1948 to $195^{2}$ alone) it is estimated that Israel built $35^{\circ}$ of the 370 new Jewish-only settlements on

109 As it stands, there is no single authoritative academic source for determining the population of Palestinian refugees and IDPs. However, recent scholarly research and publications have revealed that the number of internally displaced Palestinians during the years of 1947-1950 were higher than the number Peretz quotes. One of the foremost academic data and statistical resource centres in the world on Palestinian refugees and IDPs, the Survey on Palestinian Refugees and Internally Displaced Persons 2008-2009, published by the Badil Resource Center for Palestinian Residency and Refugee Rights, explains that by the year 1950, the number of registered IDPs in the pre-1967 Israeli territories was 47,610 persons. In this report Badil explains that: "Internally displaced Palestinians can be divided into two groups. The first is composed of persons displaced in the area that became the State of Israel in 1948. This group includes those who were displaced in the $1948 \mathrm{Nakba}$ (approximately 335,00o persons) as well as those subsequently displaced by the State of Israel. No authoritative data exists for this second category. .... The second group (approximately 129,000 persons) is composed of Palestinians internally displaced in the OPT since 1967 as a result of Israel's occupation, apartheid and colonization of the area. This figure includes Palestinian refugees who suffered subsequent secondary forced displacement inside the OPT, and whose numbers are estimated to be 37,000 persons at the end of 2008" (Badil 2009, 57-59). 
lands appropriated under The Absentee Property Law (1950). ${ }^{110}$ Severely criticized by both Arab and Jewish voices and Members of Knesset, the law was seen to grant broad executive powers to the Custodian without effective monitoring. As Tawfik Toubi, then Communist Party Member of Israel's first Knesset and one of the first to propose the formula for Israel as 'a state of all its citizens', states:

This law is a symbol, it is an expression of the discrimination practiced against the Arabs of this country .... By virtue of the provisions of this law, thousands of the Arab inhabitants of Israel are regarded as 'absentees' although they are citizens of the country. They are deprived of their rights to the use of their property. The custodian, with the help of the [Absentee Property Law ] ... of course, is stripping them of their rights as citizens. This law does not allow them to enjoy their rights to their land and their homes and they are quite unjustifiably regarded as 'absentees' .... The real assignment of the honourable custodian is to steal more and more [land] (Jiryis $1976,87)$.

All in all, land and property laws work in conjunction with a series of other Israeli laws that favour the Jewish population over the Arab citizens of the state. By now it is well documented that one of the methods employed by the state to deprive Palestinians of their land is to turn it into state land that is maintained by Jewish national and regional planning groups. ${ }^{111} \mathrm{In}$ 1960-1961, The Basic Law: Israel Lands, The Israel Lands Law and The Israel Lands Administration Law was formulated on behalf of the government of Israel to formalize its land regime so that the land controlled by the JNF would now be administered by a single authority, the ILA. Here it was agreed that "the lands controlled by the ILA shall be administered according to the principles of the JNF," and the objective of purchasing and developing land as a national resource of the Jewish people, by the Jewish people, and for the Jewish people. ${ }^{112}$ As such, the ILA is forbidden from selling or leasing the land to non-Jews. This extra-territorialization of the land places it beyond the control of the government, rendering it inaccessible to all Arab citizens. Thus, while, prior to 1948, members of the Palestinian-Arab community owned and/or cultivated some 93-94 percent of the land in geographical Palestine, today, 93 percent of the territory of Israel is under direct control of the state. This land is administered

110 COHRE and Badil, Ruling Palestine, 41.

111 See Lustick (1980); COHRE and Badil, Ruling Palestine; Stein (1984); Zayyad (1976); and Kimmerling (1983), among others.

112 Lehn and Davis 1988, 116. See also COHRE and Badil, Ruling Palestine. 
under a tenure system that continues to deny Palestinians access in the form of leasing and cultivation.

The effects of Israel's racialized land laws are most acutely embodied in the realities faced by multiple hundreds of villages inside Israel deemed 'unrecognized' or 'illegally constructed' villages. The existence of these villages and their tens of thousands of Bedouin inhabitants is not witnessed by any official map. Rather, they are systematically subjected to state policies aimed at solidifying their absence. Despite their Israeli citizenship, Palestinian Bedouin residents of unrecognized villages constitute the most disadvantaged segment of the indigenous population remaining within the 1948-1949 borders of Israel. ${ }^{113}$ The Palestinian Bedouin of the Naqab have inhabited this land since the fifth century and were traditionally organized according semi-nomadic social systems and self-sufficient tribes that lived by grazing cattle and through seasonal agriculture. ${ }^{114}$ These inhabitants of unrecognized villages are citizens of Israel, numbering approximately 75,000 to 90,000 Arab Bedouin in the Naqab alone. ${ }^{115}$ Mainly in the southern Naqab region, Palestinian Bedouin communities residing in unrecognized villages have no local council or government representation, are not recognized by any official state-affiliated institutions, receive no government services and are ignored by all government planning projects. The denial of government services to the unrecognized villages affects nearly every area of daily life. Some of the challenges faced by residents include a lack of running water, connection to a sewage network, health services, garbage collection services, connection to the electricity network, postal services, connection to the telephone network, protection or emergency services and kindergartens and welfare services (Abu-Saad 2011, 125). Instead, the Palestinian Bedouin are subjected to an exclusionary land and planning regime making it almost impossible for them to legally build where they live. Consecutive Israeli governments have disproportionately imposed forced evictions, repeated home demolitions, and numerous other punitive initiatives against these communities.

113 Human Rights Watch, Off the Map: Land and Housing Rights Violations in Israel's Unrecognized Bedouin Villages, March 31, 2008, http://www.hrw.org/en/node/62284/ section/; Also see Masalha (2005).

114 I characterize the Bedouin Arab population as 'semi-nomadic' because while their pastoral lifestyle requires seasonal travel, their movement is mainly concentrated around major historic villages with land that is privately owned and collectively held. See Adalah: The Legal Center for Arab Minority Rights in Israel, The Arab Bedouin of the Naqab: Myths and Misconceptions.

115 Adalah: The Legal Center for Arab Minority Rights in Israel, The Inequality Report, 10. 
Because the Israeli government prohibits any permanent physical or structural development in unrecognized villages, residents are unable to legally (re)build or repair existing homes, roads, educational and health facilities, community centres, or sewage systems. Developing any of these elements on one's own property is accompanied by a constant threat of eviction and demolition, which prevents many inhabitants of unrecognized villages from building new homes or developing existing ones. As a result, unrecognized villages are usually very congested with high population densities as more than one family usually resides in a single house.

\section{ISRAELI APARTHEID: BEYOND SOUTH AFRICA}

Citizenship in Israel is funnelled through comprehensive policies of exclusion and their respective systems of control, paired with limited inclusion in all socio-political spheres. ${ }^{116}$ This incorporation regime, maintained through an uneven allocation of resources, rights and representation in Israeli society, is legitimated through the way in which social membership is conceived and granted within the state. As pointed to in this book, in the case of Israel, the Jewish state is not only a source of identity but it is also a particular guarantor of rights (Kimmerling 1999).117 This is because Jewish identity in Israel provides an entirely new assemblage of rights irrespective of formal citizenship. Put differently, Jewish identity is automatically merged with Israeli citizenship.

Like other incorporation regimes, Israeli citizenship is composed of "concentric circles" within which the boundaries of civic status for the Palestinian community are distinctly rigid given their peripheral location (Shafir and Peled 1998, 412). And so, this community is limited to a rigidly defined citizenship located in the periphery, as any possibility for movement toward the centre requires a social mobility that is systematically denied to it by virtue of the self-definition of the state as 'Jewish'. In other words, the fruition of social mobility requires more rights and greater access to resources which, when denied, reduces Arab citizenship. An examination of Israel's formal and informal practices reveals that its incorporation regime is structured in the form of an apartheid state system: legally enshrined systematic discrimination maintaining the dominance

116 A similar formulation is made by Ghanem $(1998,431)$.

117 For an in-depth account of how the Zionist incorporation regime fuses Jewish and Israeli identity, see Chapter Five. 
of one "ethnic" or "racial" group over another. Resulting from the apartheid structure of the Israeli legal and political regime is a dynamic where, in principle, Israel enables its Palestinian citizens to engage in public economic, political, cultural and social life, but it does not offer equality. Instead, through apartheid policies and practices the state ensures Jewish ascendancy in all areas, actively elevating their symbolic, structural, and political presence. Israel permits its Palestinian-Arab citizens to exercise basic rights, however limited, yet these rights are funnelled through apartheid policies of domination and control that guarantee continued Arab marginality in all social, political and legal spheres (Ghanem 2001).

The discourse of Israeli crimes of apartheid is far from novel. Surfacing most acutely in the 1980 s and 1990s, a range of academic and activist publications put forth the argument that the political regime both inside Israel and the occupied Palestinian areas of the West Bank and Gaza Strip is one of apartheid. ${ }^{118}$ Heavily popularized since the 1940s, the Afrikaans word "apartheid" means to "separate," "detach" or "keep apart," and is historically and politically associated with the practices and policies of the South African Apartheid regime from $1948-1994 .{ }^{119}$ Now, it is important to note that both conceptually and practically, apartheid functions differently from racism. In a sequel to his seminal book Israel: An Apartheid State (1987), Palestinian-Hebrew scholar Uri Davis's Apartheid Israel: Possibilities for the Struggle Within (2003) effectively outlines this distinction:

118 Pre-Oslo comparisons include, but are not limited to: Benvenisti (1984) who states that the Gaza Strip "was quickly becoming the Soweto of the State of Israel”; and prominently, Davis (1987). In 1961, South African Prime Minister Henrik Verwoerd said that the Zionists “... took Israel from the Arabs after the Arabs had lived there for a thousand years. In that, I agree with them. Israel, like South Africa, is an apartheid state" (see Kovel, 2007, 211); and finally, Goodman writes that in an interview on Israeli radio after the 1967 war, David Ben-Gurion acknowledged that Israel would develop into an apartheid state should it fail to "rid itself of the territories and their Arab population as soon as possible" (see 2005, 77-79). After the 1990s when Israel introduced a multifaceted regime of control through permits, checkpoints, ID cards, military orders, closures and road blocks, the literature on Israel and the apartheid analogy has increased. This comparison has since intensified with the building of the apartheid wall in the West Bank in 2002. See, among others, Carey (2001); Bishara (2002); Farsakh (2005); Tilley (2005); Abunimah (2006); Carter (2006); and Lentin (2008).

119 Throughout this book, and in tune with other scholarly contributions on this topic, the term apartheid as legally enshrined policies and practices of racial discrimination will be written with a lower-case 'a', whereas the historical experience of the Apartheid regime in South Africa will be written with a capital 'A'. This will allow us to distinguish between apartheid as an international crime that can be committed by any state, and its historical realization in South Africa between the years 1948-1994. 
Racism is not apartheid and apartheid is not racism. Apartheid is a political system where racism is regulated in law through acts of parliament. Racism is prevalent in all states, including liberal democratic states such as the current western liberal democracies. But in liberal democratic states, those victimized by racism have legal recourse to seek the protection of the law under a democratic constitution, namely a constitution that embodies the values of the Universal Declaration of Human Rights. In an apartheid state, on the other hand, the state enforces racism through the legal system, criminalizes expressions of humanitarian concern and obligates the citizenry through acts of parliament to make racist choices and perform racist behaviour. ${ }^{120}$

The intellectual and political awareness that Israel is an apartheid state and challenges to projections of the Jewish state as 'the only democracy in the Middle East' have existed for many years among most post- and antiZionists in Israel and abroad. However, though numerous legal, political and historical comparisons between the State of Israel and Apartheid South Africa have been published, few have provided a systematic legal account of the apartheid regime in Israel that includes the whole of Palestinian society, including Palestinian citizens of Israel, Palestinians in Jerusalem, the West Bank and Gaza Strip, and the Palestinian refugee population. This point was raised by Karine Mac Allister in "The Applicability of the Crime of Apartheid to Israel," where she attempts to provide a legal framework that considers the apartheid policies and practices of the Israeli regime against the whole of the Palestinian nation on both sides of the 'Green Line'.

Mac Allister writes that "wherever they are and whatever their legal status ... Palestinian citizens of Israel, refugees, and those in the OPT are victims, albeit in different ways, of Israel's regime of apartheid."121 That said, and Mac Allister and others have pointed to this, when discussing Israeli crimes of apartheid we are not negating the fact that Israel's

120 Davis 2003, 37. An important source for students of the Zionist-Palestinian conflict, Davis's 2003 follow-up to his outline of Israeli apartheid, written over a decade prior, laid out, in great detail, Israel's blatant violations of international law and most United Nations General Assembly and Security Council resolutions, and goes on to challenge Israel's popular and mainstream characterizations in Western academic and political spaces as the 'only democracy in the Middle East'. Indeed, Davis's contribution here is key for any challenge to liberal-Zionist defences of the Zionist incorporation regime. Also, as an extension of his anti-Zionist politics, Davis identifies himself as as a 'Palestinian-Hebrew' national of Jewish origin.

121 Karine Mac Allister, “Applicability of the Crime of Apartheid to Israel," Badil Resource Center for Palestinian Residency and Refugee Rights, al-Majdal, no. $3^{8}$ (Summer 20o8), http://www.badil.org/en/al-majdal/item/72-applicability-of-the-crime-of-apartheid -to-israel. 
multifaceted system of control and expulsion of the Palestinian nation is also one of intense settler colonialism and occupation. This point was made by United Nations Special Rapporteur, John Dugard, in a 2007 Report on the situation of human rights in the Palestinian territories occupied by Israel since 1967:

The international community has identified three regimes as inimical to human rights- colonialism, apartheid and foreign occupation. Israel is clearly in military occupation of the OPT. At the same time elements of the occupation constitute forms of colonialism and of apartheid, which are contrary to international law. What are the legal consequences of a regime of prolonged occupation with features of colonialism and apartheid for the occupied people, the occupying Power and third States? It is suggested that this question might appropriately be put to the International Court of Justice for a further advisory opinion. ${ }^{122}$

The objective of military occupation differs from that of apartheid. In principle, military occupation is not arranged in the form of a long-term oppressive regime of control; rather it is understood as a temporary postconflict mechanism for ensuring law, stability and security in a certain territory. Of course, this account does not apply to the Israeli military occupation of the West Bank and Gaza Strip - one of the longest occupations in modern history. In other words, Israel's ongoing military presence is not a 'normal' type of occupation. In a separate article, Dugard writes:

Since 1967 Israel has imposed its control over the Palestinian territories in the manner of a colonizing power, under the guise of occupation. It has permanently seized the territories' most desirable parts - the holy sites in East Jerusalem, Hebron and Bethlehem and the fertile agricultural lands along the Western border and in the Jordan Valley - and settled its own Jewish 'colonists' throughout the land.123

And, as we saw above, an analysis of colonialism is part and parcel to any account the Zionist national project in Palestine. The Judaization project that lies at the root of Zionism is, by definition, a project of exclusion: seeking to create a Jewish state for the Jewish people and simultaneously

122 United Nations General Assembly Human Rights Council, Fourth Session, Implementation of General Assembly Resolution 60/251 of 15 March 2005 Entitled 'Human Rights Council': Report of the Special Rapporteur on the situation of human rights in the Palestinian territories occupied since 1967, John Dugard, (A/HRC/4/17), January 29, 2007, http://ap.ohchr.org/documents/dpage_e.aspx?m=91.

123 John Dugard, "Apartheid: Israelis adopt what South Africa dropped," The Electronic Intifada, November 29, 2006, http://electronicintifada.net/content/apartheid-israelis -adopt-what-south-africa-dropped/6568. 
rejecting the rights, presence and history of the non-Jewish Other. Thus, the measures of apartheid applied by the Israeli establishment are endemic to the settler-colonial enterprise that fuels the political Zionist project. Here Israel's settler-colonial project, mechanisms of occupation and apartheid function in conjunction with, and are amplified by, one another. In essence, when determining what kind of citizenship regime or system of control exists in all Israeli-administered territories, we must include an account of settler colonialism, occupation and apartheid, and examine ways in which their respective policies and practices are merged. On this merging of the three regimes of oppression, Dugard asks an important - and still unanswered - question:

What are the legal consequences of a regime of occupation that has continued for nearly 40 years? Clearly none of the obligations imposed on the occupying power are reduced as a result of such a prolonged occupation. But what are the legal consequences when such a regime has acquired some of the characteristics of colonialism and apartheid? Does it continue to be a lawful regime? Or does it cease to be a lawful regime, particularly in respect of 'measures aimed at the occupants' own interests'? And if this is the position, what are the legal consequences for the occupied people, the occupying Power and third States? ${ }^{124}$

Now, when identifying the Israeli incorporation regime as structured in the form of an apartheid state system, Mac Allister begins by pointing out that in order to determine whether the policies and practices of consecutive Israeli governments can be defined as apartheid in nature, one must first identify the racial groups that are placed in a relation of legally entrenched domination with one another. Regarding ascription of the crime of apartheid to the State of Israel, the two relevant racial or ethnic groups are Palestinian nationals and Zionist Jewish-Israelis. ${ }^{125}$ Mac Allister contends:

The victims of apartheid, in the Israeli case, are the Palestinian people, namely persons belonging to the Palestinian nation. For Palestinians, the test is whether they identify themselves as Palestinian nationals. If they do, and regardless of their geographic location or legal status, they constitute one 'racial' or 'ethnic' group because of their shared identity, which for instance includes a common culture, history and origin. .... In the case of the dominant group and perpetrators of apartheid, the test is based on

${ }^{124}$ United Nations General Assembly Human Rights Council, Report of the Special Rapporteur ... John Dugard.

125 Mac Allister, "Applicability of the Crime of Apartheid to Israel," al-Majdal. 
whether people identify themselves as Jewish citizens of Israel and Zionists. ${ }^{126}$

And continues to qualify her observation by stating that:

Not all Jews, however, have exercised their privilege and acquired Israeli citizenship. Hence, not all people of Jewish faith can be considered part of one racial or ethnic group in the context of the Israeli-Palestinian conflict .... [O]nly those who have voluntarily become Israeli citizens and adhere to Israel's political ideology, Zionism, constitute the relevant 'racial' or 'ethnic' group in this context. ${ }^{127}$

Having identified the two racial or ethnic groups, Mac Allister points to the definition of apartheid in the International Convention on the Suppression and Punishment of the Crime of Apartheid (hereafter 'Convention on Apartheid'), adopted by the United Nations General Assembly in 1973. She explains that, in the Convention on Apartheid, an apartheid regime refers to "similar policies and practices of racial segregation and discrimination as practiced in southern Africa ... [with] the purpose of establishing and maintaining domination by one racial group of persons over any other racial group of persons and systematically oppressing them." 128 While historically and politically associated with and based on the South African experience with apartheid, the definition of the crime of apartheid is not limited to the case of South Africa. Indeed, the Committee on the Elimination of Racial Discrimination further explained that while "the reference to apartheid may have been directed exclusively to South Africa ... the article as adopted [condemning racial segregation and apartheid] prohibits all forms of racial segregation in all countries."129 Drawing on Mac Allister's argument, others point out that the fact that

\section{Ibid.}

127 Mac Allister notes, however, that: "While Jewish Israeli society can be considered complicit in the commission of the crime of apartheid through funding the state apparatus with their tax moneys, service in the Israeli military and other institutions involved in the commission of the crime, and otherwise, Jewish Israelis who have opposed Zionism and recognize Palestinian rights cannot be held to the same level of accountability." She continues, writing that "A framework incorporating supporters of Zionism as guilty parties in the crime of apartheid also enables us to hold international actors who have supported the Zionist project, such as Christian Zionist groups, accountable for encouraging and cooperating with the racial group that has implemented the policies and practices constituting the crime of apartheid" (ibid.).

128 Ibid.

129 United Nations High Commissioner for Human Rights, Forty-seventh session. CERD General Recommendation No. 19: Racial segregation and apartheid (Article 3), (A/50/18), August 18, 1995, http://www.unhchr.ch/tbs/doc.nsf/\%28Symbol\%29/18c91e92601301fbc125 63eeoo4c45b6; Ibid. 
apartheid is defined as a crime under the 2002 Rome Statute of the International Criminal Court, and enforced long after the apartheid regime was defeated in South Africa, attests to the fact that apartheid is a system that can be practised by any state. ${ }^{130}$ Hence, while we can emphasize historical similarities between South African Apartheid and the Israeli model of apartheid, it is nevertheless important to adopt an account that reads apartheid as a political system and a crime that can be practiced by any state. Like the crimes of genocide, torture and slavery, crimes against of humanity and war crimes, apartheid is a crime that can be committed by any state, its members, representatives, institutions, structures and organizations. As outlined in Article II of the Convention on Apartheid, this involves:

Any legislative measures and other measures calculated to prevent a racial group or groups from participation in the political, social, economic and cultural life of the country and the deliberate creation of conditions preventing the full development of such a group or groups, in particular by denying to members of a racial group or groups basic human rights and freedoms, including the right to work, the right to form recognized trade unions, the right to education, the right to leave and to return to their country, the right to a nationality, the right to freedom of movement and residence, the right to freedom of opinion and expression, and the right to freedom of peaceful assembly and association. ${ }^{131}$

Which includes:

Any measures, including legislative measures, designed to divide the population along racial lines by the creation of separate reserves and ghettos for the members of a racial group or groups, the prohibition of mixed marriages among members of various racial groups, the expropriation of landed property belonging to a racial group or groups or to members thereof. ${ }^{132}$

Of course, along with persecutions of "organizations and persons, by depriving them of fundamental rights and freedoms because they oppose apartheid."133

Denunciations of Israeli apartheid should therefore not be limited to a comparative framework or analogy. As we pointed out, unlike the South

130 Hazem Jamjoum, "Not an analogy: Israel and the crime of apartheid," The Electronic Intifada, April 03, 2009, http://electronicintifada.net/v2/article10440.shtml.

131 United Nations General Assembly, 2185th Plenary Meeting, International Convention on the Suppression and Punishment of the Crime of Apartheid, (A/RES/3068-XXVIII), November 30, 1973, Article II(c), http://www.unhcr.org/refworld/docid/3ae6b3coo.html.

132 Ibid., Article II(d).

133 Ibid., Article II(f). 
African experience, the racism of modern Israel is a particular and simultaneous outcome of all three mechanisms of settler colonialism, occupation and apartheid. Apartheid is a criminal political and legal system that can be replicated by any political agent and structure, and our condemnations of such structures should not be limited to their realization in the South African experience. Consequently, "the resulting descriptions of Israel as being 'apartheid-like' and characterizations of an apartheid analysis of Israel as an 'apartheid analogy"' are incorrect and problematic. ${ }^{134}$

Another important assertion by Mac Allister, crucial for any political position against Israeli apartheid, is that the oppressive regime of segregation is applied across the imagined borders of the country. Despite differences in the legal categorization of 'Israel proper', Jerusalem, the West Bank and Gaza Strip, and the refugee camps in the Arab world, the laws and policies of the Israeli incorporation regime maintains a geographic continuity and affects all Palestinian nationals. Granted, certain apartheid laws, policies and practices will have varied effects on different parts of the Palestinian nation. ${ }^{135}$ Nevertheless, as Mac Allister states:

A central point to keep in mind ... is that regardless of the variation in the ways in which Israeli apartheid affects different segments of the Palestinian population, since it is the same state operating on behalf of the Zionist Jewish Israeli group that is implementing these laws, policies and practices with the clear goal of establishing and maintaining the domination of that group in Israel and the OPT, then it is inaccurate to consider the violations as limited to one area; a mistake made by many in limiting their analysis of Israeli apartheid to a particular geographic area or a particular segment of Palestinian society. ${ }^{136}$

This point echoes that of Israeli Professor of political geography and urban planning, Oren Yiftachel. Defining the changing political geography of Israel-Palestine as "creeping apartheid," Yiftachel explains that it is best understood as a process where a hierarchy of rights based on ethnic affiliation has evolved to an established discriminatory legal system.

\footnotetext{
134 Jamjoum, "Not an analogy," The Electronic Intifada.

135 On this point Mac Allister gives the example of the denial of the right of return, included in Article II(c) of the Convention on Apartheid, as disproportionately targeting Palestinian refugees and internally displaced persons, inside Israel, in the West Bank and Gaza Strip, in neighbouring Arab states and overseas. Here we can also include Israeli land laws which deny Palestinian citizens access to around 93 percent of the land, along with the recent amendments to the land laws preventing the return of confiscated land to its original owners, included in Article II (d) of the Convention on Apartheid, as disproportionately targeting Palestinian citizens.

136 Mac Allister, "Applicability of the Crime of Apartheid to Israel," al-Majdal.
} 
For Yiftachel, the apartheid in Israel is "creeping" because it has yet to be openly acknowledged and sanctioned by a political movement (Yiftachel 2005, 128). Similar to Mac Allister, Yiftachel points out that the Israeli incorporation regime is geographically continuous in its treatments and containment of all Palestinian nationals. Having defined "creeping apartheid," as a stratified incorporation system, he explains that

[t]his undeclared system of control stretches over Israel proper and the occupied territories, and sees groups such as Palestinians in East Jerusalem, the West Bank and Gaza; the Druze and Bedouin within the Green Line; Orthodox and Ultra Orthodox Jews; Jewish settlers; new Jewish immigrants (termed Olim in the Israeli Zionist lexicon); and migrant workers all enjoying different de jure and de facto "packages" of rights and capabilities. The civil status of these groups is determined by their ethnicity, religiosity, and location. .... The shaping of Arabs' citizenship within the Green Line can only be understood as part of this system (Yiftachel 2011, 129-130).

My analysis of the structure of the particular Israeli incorporation regime for Palestinian citizens and its exclusive inclusive dynamics supports this contention. The Zionist settler-colonial regime and its policies and practices of exclusion are seen as belonging to the same ideological continuum, despite the various historical periods of occupation and malleable geographic borders. In spite of the varying relations of exception faced by different segments of the Palestinian population at large, of which this book will deconstruct the relation of exception embedded in Palestinian citizenship, my analysis in the coming chapters will nevertheless treat the racialized, oppressive and exclusive mechanisms of the Zionist regime as existing over a single political-geographic unit, namely, Mandate Palestine. 